\title{
STATUTORY INTERPRETATION ON THE BENCH: A SURVEY OF FORTY-TWO JUDGES ON THE FEDERAL COURTS OF APPEALS
}

\author{
Abbe R. Gluck \& Richard A. Posner
}

\section{CONTENTS}

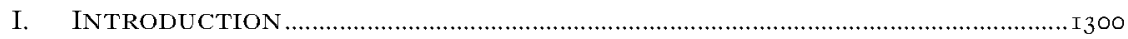

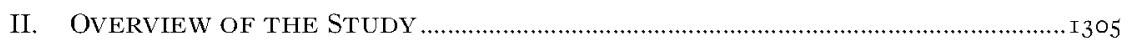

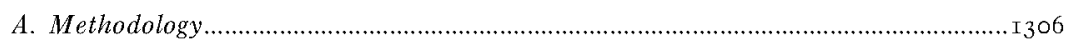

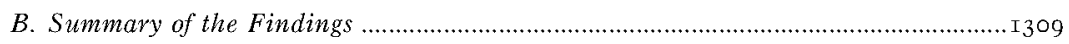

I. The Judge's Generation ...................................................................................... 3 I I

2. The D.C. Circuit Is Different ............................................................................ $3^{\mathrm{I} 2}$

3. Previous Experience Working in the Federal Government .................................... 3 I 3

C. An Overarching Impression of Widespread Eclecticism .......................................... 3 I 3

III. Do Judges Really Read the (Whole) Statute at THE Outset

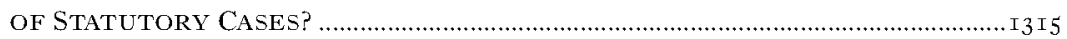

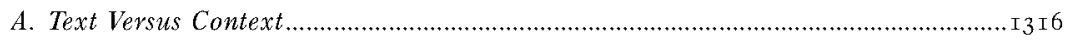

B. Dictionaries .......................................................................................................... I 3 I 7

C. The Chevron Judges: The D.C. Circuit Begins in a Different Place

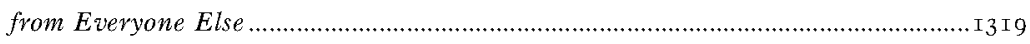

IV. Extrinsic Sources: Purpose, Legislative History, and Canons ........... I 32 I

A. Judges Did Not Wish to Label Themselves as Either Textualists or Purposivists .... 322

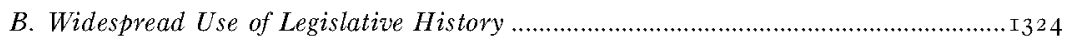

C. Almost All Judges Invoked Purpose ............................................................................ 1327

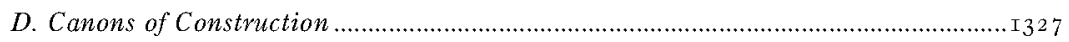

I. Canons as Tools of Persuasion, Not Decision ..................................................... $333^{\circ}$

2. Canons as Useful Decision Tools, Planted in the Judge's Mind .......................... $133^{\circ}$

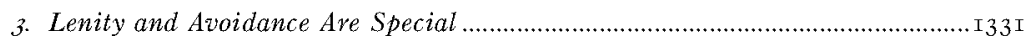

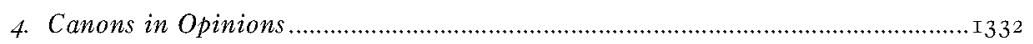

V. RELATIONSHIP WITH THE LEGISLATURE AND ROLE OF THE JUDGE ................ 3334

A. Value of Understanding Congress .............................................................................. 1335

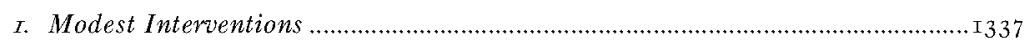

B. Imposing Consistency on Statutes ......................................................................... $333^{8}$

I. Do Not Impose Consistency Where Congress Did Not ….................................. 1338

2. Imposing Consistency and Coherence Even Where Congress Has Not

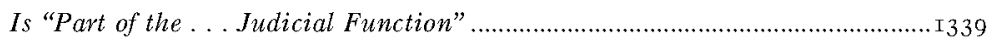

C. Interpretation to Avoid Absurdity, to Advance Common Sense, or to Update ........ 340

D. The Role of Eclecticism in the Judge-Congress Relationship Echoes of an Intent-Based Approach...... 
VI. RElationship to THE SUPREME COURT,

INCLUding THEORIES OF PRECEDENT,

I. Judges Who Believe the Supreme Court Can and Does Dictate Statutory Interpretation Rules

2. Judges Who Believe the Supreme Court Cannot Dictate Statutory Interpretation Rules.

3. Judges Who Believe the Supreme Court Could, but Has Not Yet, Dictated Interpretive Rules Because the Court Is Too Inconsistent

4. Judges Do Not Want More Guidance from the Supreme Court ……................... 347

VII. DEFERENCE TO AgenCIES AND CHEVRon SKEPTICISM ....................................... 348

VIII. MORE ON THE JUDGES' INDIVIDUAL APPROACHES ……........................................ 350

A. Judicial Approaches Adopted Incrementally, Case by Case ....................................... I 350

B. Role of Lawyers and Law Clerks ............................................................................ $35 \mathrm{I}$

C. Is Statutory Interpretation Different from Other Modes of Judicial Decisionmaking? ................................................................................. $355^{2}$

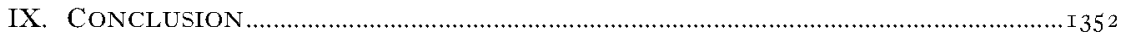

APPENDIX: REPRESENTATIVE INTERVIEWS …............................................................. 355

A. The Most Text-Oriented Type of Judge ….............................................................. 357

B. Older-Generation Judge/Legal Process Institutionalist ............................................. 360

C. Post-Scalia Canonist/Moderate Textualist $\# I$........................................................... 1362

D. Post-Scalia Canonist/Moderate Textualist \#2 …........................................................ $3_{3} 65$

E. "Ex-Staffer": Younger-Generation Judge with Some Capitol Hill Experience ........ I 369

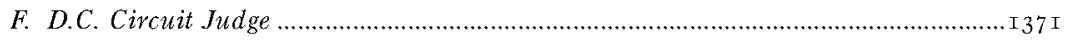




\title{
STATUTORY INTERPRETATION ON THE BENCH: A SURVEY OF FORTY-TWO JUDGES ON THE FEDERAL COURTS OF APPEALS
}

\begin{abstract}
Abbe R. Gluck* \& Richard A. Posner**
This Article reports the results of a survey of a diverse group of forty-two federal appellate judges concerning their approaches to statutory interpretation. The study reveals important differences between their approaches and the approach that the Supreme Court purports to take. It also helps to substantiate the irrelevance of the enduring, but nowboring, textualism-versus-purposivism debate. None of the judges we interviewed was willing to associate himself or herself with "textualism" without qualification. All consult legislative history. Most eschew dictionaries. All utilize at least some canons of construction, but for reasons that range from "window dressing," to the use of canons to assist in opinion writing, to a view that they are useful decision tools. Most of the judges we interviewed are not fans of Chevron, except for the judges on the D.C. Circuit, which hears the bulk of Chevron cases. Some of the judges interviewed believe that understanding Congress is important to a judge's work, while others do not see how judges can use such understanding to decide cases. Most express doubt that the Supreme Conrt's interpretive methodology binds the lower courts. The younger judges, who attended law school and practiced during the ascendance of textualism, are generally more formalist and accepting of the canons of construction, regardless of political affiliation. The older judges are less focused on canons, take a broader view of their delegated authority, and appear to grapple more with questions of judicial legitimacy.
\end{abstract}

The approach that emerged most clearly from our interviews might be described as intentional eclecticism. Most of the judges we spoke to are willing to consider many different kinds of argument and evidence, and defend that approach as the only democratically legitimate one. Yet at the same time many observe a gap between how they actually decide cases and how they write opinions, a gap they attribute to the disconnect between the expectations of the public and the realities of judicial decisionmaking.

\section{INTRODUCTION}

The vast majority of statutory interpretation cases are resolved by the federal courts of appeals, not by the Supreme Court, even though the Supreme Court's practice has received nearly all of the attention from academics and practitioners. In part due to this myopia, the Court and many academics have been mired for decades in a by-now boring School.

* Professor of Law and Faculty Director, Solomon Center for Health Law and Policy, Yale Law

** Former Judge of the U.S. Court of Appeals for the Seventh Circuit, currently President of Team Posner, Inc., a company that focuses on assisting pro se legal claimants. We are very grateful to the judges we interviewed for their candor and generosity. Special thanks also to Bill Eskridge, Patricia Goldrick, David Pozen, Amy Semet, participants at the Columbia Law School Faculty Workshop, and Yale Law School students Leslie Arffa, Miriam Becker-Cohen, Samir Doshi, Carter Greenberg, Yume Hoshijima, Julie Hutchinson, Philipp Kotlaba, Michael Morse, Max Siegel, and Matthew Sipe. 
debate about "textualism" versus "purposivism." That debate, while ostensibly about the judge's relationship to Congress and its work, has centered in practice on little more than the most appropriate evidentiary tools of interpretation: text, statutory purpose, legislative history, interpretive presumptions, and so on. Many contend that these arguments have reached détente, with most Justices now unabashedly of the "textfirst" persuasion, opting for dictionaries, interpretive presumptions, and, only after those materials, a much stingier approach to legislative history. This shift is well captured by Justice Kagan's penchant for proclaiming, like many academics, that "we're all textualists now."

This does not seem to be the state of affairs in the courts of appeals. (It is doubtful that it is the true state of affairs in the Supreme Court either, but the Court is not our focus.) This Article reports the results of a survey of forty-two federal appellate judges regarding their approaches to statutory interpretation, including their consideration of statutory text, dictionaries, the canons of construction, legislative history, and purpose. We also asked them about, among other things, pragmatism, the role of administrative agencies in statutory interpretation, and the value to judges of understanding how Congress works.

The courts of appeals have an obvious importance for everyday legal practice. Additionally motivating our study are several recent trends in case law and scholarship. First, the interpretive presumptions favored by the Supreme Court - the "canons of construction" — have taken precedence over legislative history not only in Supreme Court opinions but also in the now-widespread teaching of legislation in law schools. ${ }^{2}$ Second, some Justices and academics have claimed that the textualist approach has brought a salutary formalism to statutory interpretation $^{3}$ - a predictable methodology — even though the Supreme Court has not organized the rules in any hierarchy and does not treat its methodological rules as binding precedent on the lower courts. ${ }^{4}$ Third, two areas of academic scholarship quite relevant to the everyday work of federal appellate judges in statutory interpretation have gained traction in recent years - scholarship (and recent judicial opinions) criticizing

1 Justice Elena Kagan, The Scalia Lecture: A Dialogue with Justice Kagan on the Reading of Statutes at 8:28 (Nov. I7, 20I5), https:/www.youtube.com/watch?v=dpEtszFToTg [https:// perma.cc/7DAR-XEEN].

2 See, e.g., William N. Eskridge, JR., Abbe R. Gluck \& Victoria F. Nourse, Statutes, Regulation, AND Interpretation (20I4); JOHN F. MANNING \& MATTHEW C. STEPHENSON, LEGISLATION AND REgULATION (2d ed. 20I3); Abbe R. Gluck, The Ripple Effect of "Leg-Reg" on the Study of Legislation \& Administrative Law in the Law School Curriculum, 65 J. LEGAL EdUC. I2 I (2015); John F. Manning \& Matthew Stephenson, Legislation \& Regulation and Reform of the First Year, 65 J. LEGAL EDUC. 45, 59 (2015).

3 E.g., ANTONin SCAlia, A MATTER of Interpretation 25 (Amy Gutmann ed., i997); John F. Manning, The New Purposivism, zoI I SuP. CT. REV. I I3, I23-24.

4 See Abbe R. Gluck, The States as Laboratories of Statutory Interpretation: Methodological Consensus and the Nere Modified Textualism, I I9 YALE L.J. I 750, I765-66 (2010). 
Chevron $^{5}$ deference to agency statutory interpretations ${ }^{6}$ and scholarship on the mismatch between the realities of the congressional drafting practices and the assumptions the Supreme Court makes about how Congress works. ${ }^{7}$ We wondered how, and if, federal appellate judges have been thinking about all of these issues.

Our study reveals important differences between the approaches of the appellate judges and the approach the Supreme Court purports to take. None of the forty-two judges whom we interviewed - judges from across the political and theoretical spectrum - was willing to associate himself or herself with "textualism" without qualification. All consult legislative history. Many eschew dictionaries. Many of them utilize at least some canons of construction, but for reasons that range from "window dressing," to canons as vehicles of opinion writing, to a view that they are actually useful decision tools. Most of them are not fans of Chevron, with the significant exception of the judges we interviewed from the D.C. Circuit, the court that hears the most Chevron cases. Some believe that understanding Congress is important to the judge's work; others do not see how courts can apply such understanding or think it unwise to do so. Virtually all expressed doubt that the Supreme Court's interpretive methodology binds the lower courts, except that all consider Chevron — itself an interpretive rule — binding on them. The younger judges, most of whom were educated under the modern legislation curriculum, were generally more focused on, and accepting of, the canons of construction. The older judges, in contrast, were generally less focused on canons and took a broader view of their own authority, the legitimacy of which they viewed as coming from the delegation of legislative interpretation to courts.

The approach that emerged most clearly from our interviews is not a single approach at all but rather what might be described as intentional eclecticism. As we elaborate in the next Part of the Article, most of the judges we spoke to are willing to consider many different kinds of material. They told us it was "defensible to gather as much information as you can to make the best-informed decision you can" and that they eschewed an "ecclesiastical" ideology. Many acknowledged the

\footnotetext{
5 Chevron U.S.A. Inc. v. Nat. Res. Def. Council, Inc., 467 U.S. 837 (I984).

6 See, e.g., Gutierrez-Brizuela v. Lynch, 834 F.3d II42, II 49-58 (Ioth Cir, 20I6) (Gorsuch, J., concurring) (arguing Chevron is unconstitutional); Jack M. Beermann, Chevron at the Roberts Court: Still Failing After All These Years, 83 FORDHAM L. REV. 73I (20I4) (arguing Chevron has failed to accomplish its goals); Catherine M. Sharkey, Address at the George Mason Center for the Study of the Administrative State Rethinking Judicial Deference Conference: In the Wake of Chevron's Retreat (June 2, 20I6) (discussing ways in which the Court has retreated from Chevron), https://vimeo.com/I69758592 [https://perma.co/38RU-X 7 EZ].

7 See Abbe R. Gluck \& Lisa Schultz Bressman, Statutory Interpretation from the Inside - An Empirical Study of Congressional Drafting, Delegation, and the Canons (pts. I \& 2), 65 STAN. L. REV, 90I (20I3) [hereinafter Gluck \& Bressman, Part I], 66 STAN. L. REV. 725 (20I4) [hereinafter Gluck \& Bressman, Part $I I]$ (reporting on the findings of a survey of 137 congressional staffers and finding a disconnect between the Court's assumptions and drafters' understandings and practices).
} 
need for pragmatism - judging with common sense and an eye on consequences. Some judges offered a frank acknowledgment that sometimes the work of statutory interpretation is "quasi-legislative."

And while no judge would proclaim him or herself a "purposivist" - Justice Scalia and the textualists have too successfully denigrated that term for most to embrace it - many do seem to adopt an approach more closely associated with congressional intent than many commentators (or judges) typically acknowledge. What we heard, even from very text-centric judges, was not support of "activist" purposivism as Justice Scalia would cast it, but rather a cabined approach that seeks to implement what Congress was trying to do, using all available tools to confirm the judge's interpretation.

We did still find different areas of emphasis among judges, even though most of them claim to consult the same array of sources. We put aside the labels "textualist" and "purposivist" as unhelpful in addressing the differences among the judges. Those concepts are equally unhelpful in addressing what are, in our view, the most pressing questions of modern statutory interpretation, including the courts' relationship to Congress and the inevitability of gaps, unanswered questions, and errors in today's complex, massive statutes.

We instead suggest alternate ways to think about differences among the judges that might be more illuminating, with the caveat that a few judges straddle categories. ${ }^{8}$ In sorting among the suggested categories, we found two factors in particular - the judge's generation and whether he or she had previous work experience on Capitol Hill — to be more important than any ideological affiliation as conservative or liberal. D.C. Circuit judges seem to be a category of their own.

I. Eclectic Textualists. - These judges take a stingy, even negative, view of Congress. They prefer a textual approach where possible but, significantly, are not the same kind of textualist as Justice Scalia was. These eclectic textualists are still willing to consult broader context, purpose, canons, and even legislative history. Only four of the judges we interviewed were this type of judge, and they were the most text-centric.

2. Legal Process Institutionalists: The Older Generation. - These judges tend to be older and less focused on the realities of the congressional lawmaking process or canons and more focused on the question of delegation by Congress to courts. They are interested, in the tradition of the Legal Process movement of the I950s, in "inherent authority" and the institutional "legitimacy" of the federal courts in answering questions left open by Congress. ${ }^{9}$ These judges are the most likely to describe the judicial role as sometimes being "quasi-legislative." They do not ignore

\footnotetext{
8 One judge whom we interviewed did not fit into any of them well and is not included in the tallies for this typology.

9 Henry M. Hart, JR. \& Albert M. Sacks, The Legal Process 4-5 (William N. Eskridge, Jr. \& Philip P. Frickey eds., I994).
} 
statutory text and indeed many emphasize it, but they aim to make sense of the law within those confines and will consult whatever materials assist. We identified nineteen such judges in our sample.

3. Ex-Staffers: The Congressionalists. — These judges are strongly influenced by previous experience working in either the executive or legislative branch of the federal government. They are interested in how Congress works, do not assume that Congress is able to draft statutes perfectly, and therefore focus on legislative materials and purpose, in addition to text and canons. But they differ from what courts and academics have called "purposivists" — the category of judges typically set up as the textualists" opposites. "Purposivists" are often described as willing to interpret a statute beyond its text or original intent to accomplish Congress's goal. Justice Breyer, the current Justice most closely associated with purposivism, is indeed willing to interpret a statute beyond its four corners to "make the law work better."10 But unlike our ex-staffer/congressionalist judges, many purposivists, including Justice Breyer (himself a former staffer), have shown little interest in the realities of the lawmaking process. Our ex-staffer/congressionalists also differ from traditional purposivists in that many of these judges are more textualist (several are very closely associated with that approach in public). They deploy textualism's preferred tools, including canons, along with legislative history, with a "common sense" understanding of how Congress works. We identified eight judges in our sample who adopt this ex-staffer approach.

4. Post-Scalia Canonists. - Some of the judges unquestionably have been influenced by changes in legal education and statutory litigation over the past three decades. As recently as the early rg8os, litigants complained that they had little help from theorists, judges, or academics on what legal principles to use to frame statutory cases. ${ }^{11}$ Statutory interpretation was not a field viewed as intellectually vibrant; it was not taught in law schools. ${ }^{12}$ The textualists, who advocated a more formalist approach, are largely credited with the doctrinalization of the field. ${ }^{13}$ Textualists advanced the canons, in particular, as a more objective and

\footnotetext{
10 Stephen Breyer, Making OUR Democracy WORK 74 (20I0).

11 See Philip P. Frickey, Lecture, From the Big Sleep to the Big Heat: The Revival of Theory in Statutory Interpretation, 77 MINN. L. REV. 24 I , 242 (I992) ("Practitioners of [the I970s] who sought guidance on statutory interpretation found little available.").

12 Id. (" $[\mathrm{T}]$ he general curricular mood was one of benign neglect....").

13 See John F. Manning, Legal Realism \& The Canons' Revival, 5 GreEN BAG 2D 283, 290 (2002) ("Because textualists believe in a strong version of legislative supremacy, their skepticism about actual intent or purpose has predictably inspired renewed emphasis on the canons of interpretation, particularly the linguistic or syntactic canons of interpretation."); William N. Eskridge, Jr., The New Textualism and Normative Canons, I I3 CoLUM. L. REV. 53 I, 532-33 (20I3) (reviewing Antonin Scalia \& Brian A. Garner, Reading Law: The Interpretation of Legal TEXTS (20I2)).
} 
coordinating set of tools for resolving statutory disputes than alternatives like legislative history, ${ }^{14}$ and now Justices of all interpretive stripes use them in most statutory cases. ${ }^{15}$ Justice Scalia's last book on statutory interpretation, with Professor Bryan Garner, was exclusively about the canons. ${ }^{16}$ This doctrinalization has facilitated the teaching of legislation in most law schools - some even in the first-year core curriculum - where the canons are a central part of the materials taught. ${ }^{17}$

Many of the younger judges we interviewed had indeed been taught the canons in law school and practiced law using them, and some had taught law school classes about them. They told us they cannot stop the canons from "popping in [their] mind[s]." Some are former staffers and so recognize the canons' tension with some aspects of congressional drafting, even as they find the canons helpful as tiebreakers in deciding cases or reaching consensus with colleagues. We identified ten judges in our sample with this "Post-Scalia" canonist mindset, though we note that almost all of them emphasize other considerations, such as pragmatism, more than Justice Scalia did.

5. D.C. Circuit Judges. - The D.C. Circuit judges we interviewed fall into the categories outlined above but they begin cases very differently from all of the others. For them, every statutory question begins with the threshold question of deference to an administrative agency. As we detail in Part II, that process gives them a different perspective on their role.

We return to these categories in the pages that follow, as we detail the findings. We now proceed to an overview of our study. We then discuss the judges' responses by topic, and offer our observations about the study's implications for the field of statutory interpretation. The Article concludes with summaries of some representative interviews.

\section{OVERVIEW OF 'THE STUdY}

Our interest in this study grew out of the intersection of our previous work on statutory interpretation. Posner has written extensively about

14 See John F. Manning, Textualism and Legislative Intent, 9I VA. L. REV. 4I9, 433-36 (2005).

15 See Anita S. Krishnakumar, Dueling Canons, 65 DUkE L.J. g09, 922, 994-95 (2016) (cataloging the rates at which various Justices relied on interpretive canons and tools of construction across five-and-a-half terms). Professor Nina Mendelson's empirical study, the summary results of which are forthcoming in the Michigan Law Review, has found that all current Justices except Justice Gorsuch (who was too new to study) applied at least one canon with approval in most majority opinions they authored in cases resolving statutory issues. Nina A. Mendelson, Change, Creation, and Unpredictability in Statutory Interpretation: Interpretive Canon Use in the Roberts Court's First Decade, I 7 MICH. L. REV. (forthcoming Oct. 20I8).

16 SCALIA \& GARNER, supra note I3.

17 Gluck, supra note 2, at 157. 
how judges decide cases. ${ }^{18}$ Gluck's work has focused on the role of doctrine in statutory interpretation and what linkages exist between the interpretive doctrines applied by courts and the way that Congress actually works. ${ }^{19}$ Following on the Gluck-Bressman empirical survey of I37 congressional counsels - which asked staffers about their knowledge of and agreement with the assumptions about legislation that the Supreme Court applies to statutory cases - we thought it would be illuminating to survey federal appellate judges about their own approaches and their views of Congress, the Court, and the prevailing interpretive doctrines. We also share a strong belief in the merits of turning more scholarly attention away from the Supreme Court and instead to the everyday decisionmakers in the system. ${ }^{20}$

\section{A. Methodology}

In the summer of 2014 , we received approval for this study from an Institutional Review Board, ${ }^{21}$ and then sent letters of invitation to forty federal court of appeals judges to participate in our survey. Judges were assured that their identities would not be revealed and that all participants would be interviewed by one or both of us, either in person or over the phone. Thirty of the judges accepted our invitation, and we interviewed twenty-nine of them. ${ }^{22}$ Early in 2015, we invited thirteen

18 Richard A. Posner, How Judges Think (2008); Richard A. Posner, REFLECTIONS ON JUDGING (20I3).

19 See, e.g., Abbe R. Gluck, Intersystemic Statutory Interpretation: Methodology as "Law" and the Erie Doctrine, I20 YALE L.J. I898 (20II) (finding that federal courts of appeals do not treat statutory interpretation doctrine as "law" as they would treat doctrine in other fields); Gluck, supra note 4 (reporting the findings of a study of statutory interpretation in state courts); Gluck \& Bressman, Part I, supra note 7; Abbe R. Gluck et al., Essay, Unorthodox Lawmaking, Unorthodox Rulemaking, I 5 COLUM. L. REV. I789 (2015).

20 See, e.g., POSNer, How JudGes THINk, supra note I8; Gluck, supra note ig (focusing on interaction between state courts and lower federal courts); Abbe R. Gluck, Essay, Intrastatutory Federalism and Statutory Interpretation: State Implementation of Federal Law in Health Reform and Beyond, I2 I YALE L.J. 534 (20II) (focusing on state administrators and courts); Gluck, supra note 4 (focusing on state courts). For a few exceptions to the myopic focus on the Court, see, for example, Frank B. Cross, Decision Making in the U.S. Courts of ApPeals (2007); James J. Brudney \& Lawrence Baum, Dictionaries 2.0: Exploring the Gap Between the Supreme Court and Courts of Appeals, I25 YALE L.J.F. IO4 (20I5); James J. Brudney \& Lawrence Baum, Protean Statutory Interpretation in the Courts of Appeals, 58 WM. \& MARY L. REV. 68I (20I7) [hereinafter Brudney \& Baum, Protean Statutory Interpretation]; and Aaron-Andrew P. Bruhl \& Ethan J. Leib, Elected Judges and Statutory Interpretation, 79 U. CHI. L. REV. I 2 I5 (20I2).

21 IRBs are ethics committees that monitor research involving "human subjects" for risk and protect the rights of subjects. See Yale Univ. Institutional Review Bds., IRB PoliCy IOO INSTITUtIONAL REVIEW BOARD REVIEW OF HUMAN SUBJECT RESEARCH PROTOCOLS OR FDA-Regulated ACtivities Involving HuMAN PARTICIPANTs (2015), https:/your. yale.edu/sites/default/files/irb-policy-Ioo-institutional-review-board-irb-review-human-subject.pdf [https:/perma.cc/6 $\mathrm{H}_{4} \mathrm{~S}_{-9} \mathrm{RCX}$ ].

22 One judge wished to be interviewed only in person and we were unable to arrange a mutually convenient time for travel to chambers. 
more judges to participate, and six accepted, bringing the tally to thirtyfive. In 2017 , we used a random-number generator to select twenty-five more judges. Of the judges randomly generated, seven were already in our sample. We sent letters to the next ten on that list, and interviewed three of them. We then reviewed our sample for diversity across many metrics, including geography, age, gender, and race and invited another ten judges to participate who we thought would make our sample more representative; four responded and we interviewed them all, bringing the final number to forty-two. About three-fourths of the interviews took place over the phone, the rest in person. We initially divided the interviews between the two of us but soon discovered that we preferred interviewing together for ease of notetaking and comparing impressions. All notes were taken by hand and there were no recordings; we surmised most judges would not feel comfortable being audiotaped. Each interview lasted approximately one hour and followed the same script of nineteen questions. ${ }^{23}$

We do not claim to have a random sample, but we did attempt to speak with a diverse group of judges. Our invitation list included judges from all of the federal courts of appeals, appointed by Presidents of both parties; of different ages but having at least three years of service on the federal appellate bench; of different races and genders; and with known differences in interpretive methodologies. Where a circuit included a judge known for his or her strong views on statutory interpretation, we invited that judge but also invited another judge from the same circuit with a different perspective. We also invited many judges not associated with any particular perspective at all. Our goals were geographic, experiential, ideological, and demographic diversity. Notably, the judges who were selected by the random-number-generation technique gave responses that did not differ in any significant way from the judges who were not.

There is always a risk of response bias in studies of this nature, and we make no claim that our sample is representative or predictive. There is also the possibility that judges do not do all of the interpretive work that they claim they do, perhaps delegating much of it to law clerks. The interviews might also have a performative aspect — judges may have told us what they thought we wanted to hear. But as the interview summaries suggest, the judges we interviewed seemed conscientious, and how judges describe their own approaches, even if their descriptions do not fully capture their actual approaches, is interesting. Most of the judges with whom we spoke admitted at some point in the interview a lack of knowledge, or not having thought deeply about an issue, or a

23 After the first set of interviews, we made minor changes to clarify the wording of questions about which the judges we interviewed had needed clarification. There were also four additional questions that we experimented with using, but which ultimately were asked to only a handful of judges, and so we do not include the answers as part of our results. 
lack of a coherent theory - a degree of candor that suggests they were not posturing. We also compared interview responses across interviews conducted by Posner alone, by Gluck alone, and by both together and found no significant differences based on the interviewer.

In addition we examined a random sample of fifteen to twenty opinions of all of the judges whom we interviewed. Sampling allowed us to see the variety of interpretive tools judges use, and thus allowed us to compare to some extent how they describe their approaches to statutory interpretation with what they actually do. Again, we do not make claims of scientific precision. For judges who have written a great many opinions, sampling cannot provide a complete snapshot of their interpretive approaches or what tools they use, in large part because there are so many potential tools. Sampling was most helpful to disprove the negative. For instance, sampling allowed us to see that even judges who said they do not use canons, do. It allowed us to confirm, too, that all of the judges consulted dictionaries and legislative history, as they told us they did. For judges with many opinions, a much more detailed review of the opinions authored would be required to make more definitive claims.

As another check, we randomly selected half of the judges and surveyed all of their statutory interpretation majority opinions for possible effects of judicial panels on certain interpretive methods. We examined whether those judges used dictionaries or legislative history more or less frequently depending on the composition of the panel by the party of the appointing President. (We chose dictionaries and legislative history as admittedly rough proxies for this test because they are the easiest-toidentify signals of a textualist and purposivist approach, respectively. ${ }^{24}$ ) We could not infer any significant effects. But we did observe some interesting patterns that might be worthy of exploration in the future. For example, and perhaps unsurprising, eight of twelve liberal judges used legislative history more often on panels with only liberal colleagues. However, more surprising, three of twelve liberals used legislative history more frequently with conservatives; four of nine conservatives used legislative history more on panels with only other conservatives, and five of nine conservatives used dictionaries more frequently with liberals. On the whole, while no firm conclusions can be drawn from this rudimentary examination, the exercise nevertheless was useful because it both corroborated what judges told us they did — the judges who stated in interviews that they rarely or often used these materials did indeed rarely or often use them - and revealed relatively stable interpretive approaches across opinions.

Of the forty-two (out of the I69 sitting) federal court of appeals judges whom we interviewed, eight were women (women comprise

24 We also normalized the results to correct for the fact that certain judges sat more frequently on liberal, conservative, or mixed panels. 
slightly more than one third of judges on the courts of appeals); thirtytwo were (non-Latino) Caucasian (we interviewed ten out of the fortyeight non-Caucasian judges serving at the time of our study); nineteen had been appointed to the court of appeals by a Republican President and twenty-three by a Democratic President; and eight were under sixty (The average age of all judges - active and senior — on the courts of appeals is 7 I.2). ${ }^{25}$ All the courts of appeals except the Eighth and Eleventh Circuits (no judges from those circuits accepted our invitation) were represented. Using another measure, our judges occupy a broad ideological spectrum on the Judicial Common Space (JSC), an instrument that includes all Supreme Court Justices and Court of Appeals judges who served between 1953 and $2013 .{ }^{26}$ Seventeen of the judges we interviewed were estimated to be between the twenty-fifth and seventy-fifth JCS percentiles, with eight estimated to be conservative (above the median) and seven estimated to be liberal (below the median). The twenty-five remaining judges exhibited more extreme ideological preferences. Of those, eleven were estimated to be particularly conservative (above the seventy-fifth percentile) while fourteen were estimated to be particularly liberal (below the twenty-fifth percentile).

\section{B. Summary of the Findings}

Our interview questions drew from the current academic and judicial debates over statutory interpretation. Focusing first on the current Supreme Court's text-focused approach, we asked each judge about his or her own approach to the Court's favored tools, namely statutory text, dictionaries, and the canons of construction. We then asked about legislative history and statutory purpose - tools of interpretation that academics have argued have fallen out of some favor in the federal courts, largely due to the influence of textualism. We moved next to the newer questions that have emerged in the field, including the relevance of understanding how Congress operates to the work of judges in statutory cases, ${ }^{27}$ and whether it is the judge's role to repair statutes - that is, to make them more consistent or more sensible. ${ }^{28}$ We also asked about

25 Data on file with authors.

26 See Lee Epstein et al,, The Judicial Common Space, 23 J.L. ECON. \& ORG. 303 (2007); Micheal W. Giles, Research Note, Picking Federal Judges: A Note on Policy and Partisan Selection Agendas, 54 POL. RES. Q. 623 (200I). Judges who are estimated to be conservative are assigned to a positive score, while those estimated to be liberal are assigned a negative one. The median JCS score is .OI. We categorized each judge interveiwed in reference to the twenty-fifth $(-0.294)$ and seventy-fifth (0.3055) JCS percentiles, creating four ideological types.

27 See generally Gluck \& Bressman, Part I, supra note 7 ; Gluck \& Bressman, Part II, supra note 7 .

28 Cf. Hively v. Ivy Tech Cmty. Coll., 853 F.3d 339, 352 (7th Cir. 20I 7) (en banc) (Posner, J., concurring) (noting that one method of interpreting a statement found in a constitutional or statutory text is to "infuse[] the statement with vitality and significance today"). 
another subject of Gluck's research: the precedential weight of the Supreme Court's pronouncements about statutory interpretation. ${ }^{29}$

In addition, we asked about deference to federal agency statutory interpretations; the role of lawyers and law clerks in statutory cases; and how if at all statutory cases differ from other types of cases. We also asked each judge how he or she had developed his or her own interpretive approach and what "one word" would best describe that approach. Several months after the initial round of the survey concluded, we followed up with three additional questions, which were about the eclecticism we had observed, the propriety of updating old statutes, and how a statutory interpretation decision gels in the judge's mind in a particular case. Nineteen of the thirty-five judges interviewed before spring $20 \mathrm{I} 7$ responded to the follow-up questions. All judges interviewed after spring 2017 were asked the follow-up questions at the end of their initial interview.

As a note, our survey questions do not track the questions that the Gluck-Bressman survey posed to congressional staff. We did not think it respectful to quiz the judges about their specific canon knowledge, or productive to grill them on the particulars of the legislative process. Instead our questions for the judges were more topic-oriented, aimed to open discussion. ${ }^{30}$

Several major themes emerge from the responses. First, what divides judges is not what academics and judges think divides judges. None of the judges is a "textualist" in the extreme sense of that word, or even in the version of textualism that was practiced by Justice Scalia. Very few judges told us they read the entire statute, or even begin their analysis of statutory cases with the text of the statute. All of the judges use legislative history. Dictionaries are mostly disfavored. Even when asked to provide one word to describe their interpretive approaches, not one judge was willing to self-describe as "textualist" without qualification. Even the text-centric judges described themselves in such terms as "textualist-pragmatist" or "textualist-contextualist." Our findings reveal the academic cliché de mode — "we are all textualists now" 11 — to be an overstatement.

At the other end of the spectrum, however, there were no extreme purposivists either, in the sense of the purposivism that has been textualism's foil. No judge stated that purpose was a more important tool

29 See Gluck, supra note I9, at I907-18; Abbe R. Gluck, The Federal Common Law of Statutory Interpretation: Erie for the Age of Statutes, 54 WM. \& MARY L. REV. 753 (20I3).

30 It is for this reason that we offer examples in many of our questions. For instance, when we asked judges if they use canons, we defined some canons for them. We recognize this method of questioning may bring some criticism of leading, but we selected this manner of questioning to create an atmosphere of respect and trust, which in turn encouraged an open discussion.

31 Jonathan R. Siegel, Textualism and Contextualism in Administrative Law, 78 B.U. L. REV. I023, I057 ( 1998 ); see Jonathan R. Siegel, The Inexorable Radicalization of Textualism, I58 U. PA. L. REV. I 7 7, I33 (2009); Kagan, supra note I. 
than statutory text, and only one judge claimed to begin analysis of a statutory case with the statute's purpose. Even those judges who emphasized the importance of purpose as an interpretive tool made clear they still would not use purpose to push a statute's interpretation beyond the limits of its text.

And when it comes to tools of decision, the biggest divisions among the judges interviewed had nothing to do with text, legislative history, or canons - the topics that dominate and divide Supreme Court opinions and academic discourse. Also, no significant differences could be found simply by looking at the political party of the President who had appointed the judge, or at other personal factors such as the judge's gender or race, at least based on our limited sample. Among the judges we interviewed, the greatest divisions resulted from the three factors that we already have introduced and now further detail: the judge's age, whether he or she sits on the D.C. Circuit, and prior experience working on Capitol Hill. These factors have received almost no theoretical attention.

I. The Judge's Generation. - The judges over the age of seventy, regardless of political affiliation, were much more focused on questions about the inherent power and duty of the federal courts in statutory cases than on any interpretive dogmas. Above we called these judges the "legal process institutionalists." They were more forthright about the quasi-legislative activity that statutory interpretation by judges entails, and discussed openly whether gaps in statutes could be understood as delegation by Congress to the courts. This position gels with Posner's work, which has emphasized that statutory interpretation, in reality, often entails more than merely searching for original meaning. Posner identifies two additional general categories of statutory interpretation: giving meaning to "unexpressed intent" and "giving a fresh meaning to a statement" by "making old law satisfy modern needs and understandings." "32 In such situations, the judge's function is, realistically, more legislative than interpretive. Many of the older judges recognized this, especially with regard to unexpressed intent (we encountered more resistance to the idea of updating, as detailed in Part V).

The younger judges, on the other hand, many of whom went to law school in the ig8os or later, advanced a more rule-oriented approach. These are who we call the "canonists." Most of them, as noted, are very familiar with the canons of construction, either through their legal education or their litigation and advocacy experience - and have them at the forefront of their thinking. They do not seem to focus on the bigpicture questions about the judicial role and inherent authority that we heard emphasized by the older judges - indeed, they seem more insecure than the older judges that they even have such authority. This is not a division that tracks the political party of the nominating President.

32 Hively, 853 F.3d at 352 (Posner, J., concurring). 
Instead, the general influence of formalism on this generation of judges seems to carry across the board. We heard Justice Scalia's and textualism's influences emphasized by younger judges of all political backgrounds. As one liberal judge told us:

I use [the canons]. I feel obliged to use them. I try to think about what it means and these things are popping into my mind. If I had been educated differently maybe other things would pop into my mind. I can't help it.

Another said:

I'm in the post-Scalia world and very much grew up in that, so the first thing I do is look to the immediate text and then I zoom out and look at the sections and see where it fits into the context. Then ... I'll look to where that section is cross-referenced in the statute, or if the same term is being used in other sections or surrounding provisions .... I think about Congress's goals in a given statute, but more through the canons of construction. . . . In terms of legislative history ... I don't rule it out, but I'm the poster child for how statutory interpretation has developed over time, Scalia's impact, because in opinions I do write things, only at the very end, like "we need not rely on it but to the extent there is any doubt it is put to rest by the committee report." Always with that proviso.

Trends in legal education, including the new courses in statutory interpretation that tend to highlight the influence of textualism on the field, ${ }^{33}$ alongside the virtual disappearance of legal process theory from most American law school curricula, ${ }^{34}$ are likely playing an important role in this generational shift.

There are of course differences within the groups, some of which come from intersections with other themes that emerged from our study. For instance, the younger judges with Capitol Hill experience were more critical of some of the canons than other judges of the same generation, especially when the canons adopt an unrealistic view of the legislative process.

2. The D.C. Circuit Is Different. - A second major theme that emerges is that the D.C. Circuit judges appear different from the others.

33 See Gluck, supra note 2, at I 57 (finding the courses focus on canons and debates over legislative history).

34 Cf. Guido Calabresi, An Introduction to Legal Thought: Four Approaches to Law and to the Allocation of Body Parts, 55 STAN. L. REV, 2 I I3, 2 I 22-26 (2003); William N. Eskridge, Jr. \& Philip P. Frickey, Legislation Scholarship and Pedagogy in the Post-Legal Process Era, 48 U. PITT. L. REV. 69I, 694 ( 1987 ) ("Scholars have significantly expanded the agenda for legislation by reconceptualizing legal doctrine through models and insights from other academic disciplines and by criticizing the ideological assumptions of the Hart \& Sacks approach."); id. at 693 ("Today, alternative philosophies of law ... challenge the legal process consensus."); Jeremy K. Kessler \& David E. Pozen, Working Themselves Impure: A Life Cycle Theory of Legal Theories, 83 U. CHI. L. REV. I8 I9, I82829 (20I6) "Today's leading public law theories depart from the old legal process in acknowledging the normativity of legal decisionmaking and accepting that "no issues are simply "procedural."," (quoting William N. Eskridge, Jr. \& Gary Peller, The New Public Law Movement: Moderation as a Postmodern Cultural Form, 89 MICH. L. REV. 707, 762 (I99I) (emphasis added))). 
They have drunk the Chevron Kool-Aid - the decisionmaking framework that requires judges to defer to reasonable agency interpretations of ambiguous statutes. ${ }^{35}$ They find comfort in that framework and consider the question of the agency's role to be the first and most important question in statutory cases. In contrast, the vast majority of the nonD.C. Circuit judges we spoke with seriously questioned the wisdom and even legality of Chevron, especially in regard to legal questions that are not within an agency's expertise. We elaborate on our Chevron-related findings in Part VII.

3. Previous Experience Working in the Federal Government. - Previous experience working in the legislative or executive branch of the federal government, or even a state government, appears to have a significant impact on a judge's approach to statutory interpretation, at least in our sample. We found that judges with previous Capitol Hill experience are less likely to embrace many of the interpretive assumptions favored by the current Supreme Court that depend on the fiction that Congress is perfect, consistent, and omniscient.

Indeed, these "ex-staffer" judges are more likely to accept a broader judicial role, taking the view that no statutory drafter can ever foresee and encompass the full range of possible statutory applications. These judges - again regardless of political affiliation — were more interested in legislative history, understanding how Congress works, giving Congress the benefit of the doubt, and even repairing Congress's mistakes. For these reasons, unlike conventional textualists, many of these judges - even those who are publicly associated with a text-centric approach - did not put much of a premium on reading statutes to be consistent, internally coherent, nonredundant, and so on - the kinds of canons that are most favored by the Scalia/Garner treatise ${ }^{36}$ but that bear little resemblance to how Congress actually drafts.

\section{An Overarching Impression of Widespread Eclecticism}

Our overarching impression across all of the categories of judges was one of widespread eclecticism. For some judges, the eclecticism seemed intentional, as a way to make the judge confident of having reached the "correct result." One judge, known widely as a textualist, put it this way: "I just keep reading until I get comfortable. If I have to start reading a secondary text ... I will. I don't necessarily rely on everything I have read but I do keep reading." Others said that looking at all the materials is about ensuring "[we] are doing what the legislature wanted" and "to the extent judges believe it is their job to find out what Congress meant, being eclectic is inevitable." Another said: "Nobody

35 Chevron U.S.A. Inc. v. Nat. Res. Def. Council, Inc., 467 U.S. 837, 844-45 (I 984 ).

36 SCALIA \& GARNER, supra note I3, at I67-68, I70. 
endorses any other method! That's like asking me why I look at a map to get where I am going. It's the only way that makes any sense." We found these perspectives interesting and not well represented in most current scholarship about statutory interpretation. ${ }^{37}$

Some judges did seem more at sea. For these, a preference for eclecticism seems to stem from an eagerness to grasp at whatever supports are available to reinforce a conclusion and to help to explain decisions in ways that are both acceptable to colleagues of different political persuasions, and that also sound sufficiently "opinion-like" for the general public. Indeed, we heard a lot about statutory interpretation doctrine as a way to express results in opinions, rather than as a tool that actually decides cases.

One judge put it especially colorfully:

My perception is that judges are eclectic in their approaches to statutory interpretation for two principal reasons. They want to use as many tools as possible to guide their way to a ruling and to test the results of one interpretive aid against those of another; or they want no more than to find fellow travelers to support the desired result that their "priors" (to use Dick [Posner]'s word) lead them, much as a drunk uses a lamppost more for support than illumination. ... [I]t is prudent, I believe to employ the various checks and cross-checks noted above. . . Why? We need as much help as we can get.

Another judge defended the eclecticism we saw on the ground this way: "That is the essence of being a judge." He said: "You could give someone a computer and they could do our job, you could feed in all the canons, rules, etc., and it could spit out an opinion. But the essence of being a judge is the human factor."

Only a few judges articulated any general theory of their own interpretive approach. Most resisted the very question - that is, resisted the idea that their practice is driven by any organized theory. Instead they told us they move case by case, in almost a common law fashion.

Although eclecticism may not seem a particularly exciting finding, our findings may dispel some misconceptions about judging in statutory cases and may also help shift the intellectual debate to newer and more fruitful topics than the now very tired "textualism versus purposivism" debate. We think it more interesting to focus on such questions as why the canons endure and why judges are uncomfortable writing opinions without them even if they do not really use them in decisionmaking. We also find more interesting questions concerning how judges think about who (Congress? The Supreme Court?) can control their own interpretive approach; what they think their role is in helping Congress, such as correcting its mistakes; and how judges should relate to agencies that issue judicially reviewable decisions.

37 For a notable and early exception, see William N. Eskridge, Jr. \& Philip P. Frickey, Statutory Interpretation as Practical Reasoning, 42 STAN. L. REV. 32 I (I990). 
We can acknowledge that judges use a mixture of interpretive tools and then finally move past the evidentiary issue to questions like why they write opinions the way they do, and whether it undermines legitimacy that many judges do not seem to have a consistent or identifiable interpretive approach. To the extent that appellate judges are doing more common law-type judging in the statutory context than previously assumed, pragmatism may be playing a bigger role than most judges (Posner excluded) have previously publicly acknowledged.

As noted, in reviewing a random sample of each judge's opinions, we confirmed that all the judges we interviewed cited both canons and legislative history, and generally used the wide range of materials they described. Most, though not all, of the judges we interviewed rely on the parties' briefs at least some of the time to "tee up" the relevant evidentiary tools in the case. For instance, the choice among which of the many potential canons that could be cited in opinions largely comes in response to a party's own argument. But the judges themselves - or at least their law clerks drafting opinions - also are sometimes responsible for introducing canons or legislative history into an opinion.

In the next Parts, we aggregate the judges' responses across the array of topics we raised with them. At the end of the paper, to provide a more holistic picture of judicial approaches to statutory interpretation, we provide excerpts from interviews of judges of different "types" (redacted where necessary to preserve confidentiality).

\section{Do Judges ReAlly ReAd THE (WHOLE) StATUte AT THE OUTSET OF STATUTORY CASES?}

Textualists often state that they look only to the text when beginning a statutory interpretation inquiry. We have reason to doubt that this is what most judges do - especially those who claim one should read the entire statute - given the length and complexity of many modern statutes. Statutes are not narrative documents; their density and numerous cross-references make most statutes impossible even for most legislative experts to read cover to cover. Why do so many courts and theorists adopt the fiction that judges do this? We wondered whether, in practice, judges prefer to have some context about what the fight is over - for instance, by reading a bench memo, or a brief - before delving into a statutory text. Even judges who say they do not seek out statutory purpose or legislative history might still be exposed to this information, perhaps before seeing the statute's text, if they read briefs and lower court opinions before turning to the statute. We also wondered whether judges use dictionaries, which are often the first interpretive tools looked to by the current Court after plain text. 


\section{A. Text Versus Context}

Twenty-four of the judges we interviewed reported that they begin statutory interpretation with the words of the statute. But there was disagreement as to what that meant. For two of the judges, reading the statute is a pro forma exercise, apparently for "cover" in opinion writing. Both told us that they begin with the text "because the Supreme Court has told us many times we have to," but both then move quickly to other considerations, including purpose and consequences.

Three of the judges told us they begin by reading the entire statute, not just the contested provisions - which, as noted, we doubt is often possible. But these were not Scalia-style textualists. Two of these textcentrics told us they also look to legislative history if the statute is unclear, and one told us that he looks at statutory language to determine whether there is "an inherent delegation" of gap-filling power to courts. One of them will not consult a dictionary - the tool popularized by the textualists but now deployed by virtually the entire Supreme Court ${ }^{38}$ at all.

The remaining nineteen of the twenty-four judges who report beginning with text told us they begin with the words of the provision at issue but expand consideration if the statute is vague to include precedent, the evolution of the statute, and legislative history. Nine of these judges were appointed by a Republican President.

Thirteen other judges — six appointed by Republican Presidents and several of whom are publicly associated with a textualist approach told us that they do not start with the words at all, but instead begin with some combination of the briefs and the lower court opinion. They told us they do this to "understand what the issue in the case is," "to understand the problem." Some alluded to the awkwardness of admitting they do not start with the text, as if that is what the public expects judges to do.

These statements were consistent with our view that a recalibration of what we expect from judges when it comes to reading massive modern statutes may be in order. Judges should not have to apologize for beginning their inquiry into statutory questions somewhere other than the statutory text - especially in the case of statutes that are excessively lengthy, complex, or replete with cross-references and so impossible to

38 See James J. Brudney \& Lawrence Baum, Oasis or Mirage: The Supreme Court's Thirst for Dictionaries in the Rehnquist and Roberts Eras, 55 WM. \& MARY L. REV. 483, 494-502 (20I3); Jeffrey L. Kirchmeier \& Samuel A. Thumma, Scaling the Lexicon Fortress: The United States Supreme Court's Use of Dictionaries in the Twenty-First Century, 94 MARQ. L. REV. 77, 84-93 (2010) [hereinafter Kirchmeier \& Thumma, Scaling the Lexicon Fortress]; Samuel A. Thumma \& Jeffrey L. Kirchmeier, The Lexicon Has Become a Fortress: The United States Supreme Court's Use of Dictionaries, 47 BUFF. L. REv. 22 7, 256-60 (I999) [hereinafter Kirchmeier \& Thumma, The Lexicon Has Become a Fortress]. 
read sequentially. (Indeed, as the Gluck-Bressman study found, even expert congressional staffers rarely start with the text for precisely this reason. ${ }^{39}$ ) As one judge told us:

I certainly begin with the text of the statute. That's not even true. I actually begin with the parties' briefs. Then I drag out the text of the statute. I already have some grounding from the briefs in the competing interpretations ....

Another said:

No idea. I read the brief. I read whatever it is the law clerks have prepared for me ... it all starts to form an impression. At some point I read the entire statute. I could say I begin with the statute but that's not quite correct.

In the end, both the judges who start with the words of the statute and those who do not seem to us to engage in essentially the same mode of contextual analysis, which defies categorization as either textualist or purposivist. They begin by trying to understand the statute, the problem the statute addresses, and the issue in the case at a broad level of generality. This broad lens often seems necessary to understand what lengthy and complex modern statutes mean. None of the judges we spoke with was formalist about this process.

There are five more judges whom we have not aggregated above. That is because they sit on the D.C. Circuit and told us that their first question is always Chevron. We elaborate on this special feature of the D.C. Circuit below.

\section{B. Dictionaries}

Of the forty-two judges whom we interviewed, only seventeen advocated using dictionaries, even though dictionaries are a favored interpretive tool of the current Supreme Court. ${ }^{40}$ The others told us that they rarely consulted dictionaries, or preferred to consult them in two types of circumstances: (I) to ascertain technical or specialized meaning; or (2) to determine if a word has multiple meanings, which they might do by consulting several dictionaries. We asked about the use of dictionaries after we asked the judges where they begin their analysis in statutory cases and the role that "plain meaning" plays in their decisions, because dictionaries are often trotted out by the Court to substantiate a textual reading before moving on to canons or nontextual tools. Although textualists may be responsible for elevating the importance of

39 Gluck \& Bressman, Part I, supra note 7 , at 972-73 (noting many staffers begin instead with the more narrative "section-by-section" summary, $i d$. at 972 ).

40 See Brudney \& Baum, supra note 38 , at 495 (finding that the Supreme Court relied on dictionaries to define terms in 145 opinions from I 800 to 1969 ; in 89 opinions from I 969 to 1986 ; in 373 opinions during the nineteen-year Rehnquist era; and in 138 opinions during the first five terms of the Roberts Court); Kirchmeier \& Thumma, Scaling the Lexicon Fortress, supra note 38 , at 79 (finding that during the Supreme Court Terms from 2000 through 2009 , the Justices referenced dictionary definitions to define almost 300 words or phrases). 
dictionaries, the Court's liberals now use dictionaries almost as often as the Court's conservatives. As Professors James Brudney and Lawrence Baum have documented, in a subset of cases likely to require statutory interpretation between 2005 and 2010 Chief Justice Roberts cited a dictionary in $35.7 \%$ of majority opinions; Justice Scalia in $30.8 \%$; Justice Kennedy in $23.1 \%$; Justice Thomas in $35.7 \%$; Justice Ginsburg in $23.5 \%$; Justice Breyer in $28.0 \%$; Justice Alito in $33.3 \%$; Justice Sotomayor in $25.0 \%$; and Justice Kagan in $50.0 \%{ }^{41}$

Yet dictionaries strike us as an odd interpretive tool. As the GluckBressman study found, congressional drafters do not consult dictionaries when drafting. ${ }^{42}$ Dictionaries are "extrinsic" interpretive aids — aids outside of the statutory text - much as legislative history is, but dictionaries have not received the same critical scrutiny. Scholars have long pointed out that dictionaries tend to lag behind the real-life evolution of language. ${ }^{43}$ Indeed, a judge today who wishes to determine ordinary usage might be better off consulting Google. And as one of our respondents told us, if usage is truly ordinary, the judge does not need a dictionary to discover it.

A recent study catalogues the statutory terms for which the Court has consulted a dictionary in recent years. ${ }^{44}$ The terms include some very ordinary words, including "any," "also," "upon," and "shall."45 In our view, there is a difference between looking up arcane legal terminology or technical terms, like medical terms in a specialized dictionary, and looking up words like "shall" and "any." If a statute creates sufficient ambiguity that the judge doubts that by "any" or "shall" Congress really means "any" or "shall," looking those terms up in a dictionary is not going to solve the problem. That judge will have to resort to context. A number of the judges we interviewed made similar comments and told us they generally eschew dictionaries but find utility in them only for specialized, technical, or medical terms. Several judges told us they consult multiple dictionaries, and do not find dictionaries useful if they conflict.

In our random sampling, we were able to confirm for all but two of the judges that those who expressed skepticism about dictionaries were cautious about using them in opinions. Four of the judges who expressed skepticism never appeared to use them at all. Dictionaries, when used by these judges, were used with caution, much less frequently than other interpretive tools, and not for simple, everyday words like "any." As noted in Part I, we also examined all of the statutory inter

41 Brudney \& Baum, supra note 38 , at 522 .

42 See Gluck \& Bressman, Part I, supra note 7 , at 938.

43 See Brudney \& Baum, supra note 38 , at 502; Kirchmeier \& Thumma, The Lexicon Has Become a Fortress, supra note 38 , at 243,294 .

44 Kirchmeier \& Thumma, Scaling the Lexicon Fortress, supra note 38.

45 Id. app. at I35, I72, I77. 
pretation majority opinions for twenty-one of the judges, randomly selected. Setting aside one recently appointed circuit judge without a long record of decisions, the four heaviest dictionary users relied on dictionaries in between 29 to $32 \%$ of statutory interpretation cases. The median judge relied on dictionaries in about $10 \%$ of cases. On the low end, six of the judges relied on dictionaries in $5 \%$ or less of cases, and two of the judges never relied on dictionaries. In all but the same two cases noted above, the judges who told us they used dictionaries frequently or infrequently adopted that approach in their opinions. Our assessment of all of these cases also confirmed the judges' claims that they rarely used dictionaries for everyday words. Across our sample, the judges used dictionaries for everyday words in less than $0.5 \%$ of statutory interpretation cases.

We also were able to confirm from the opinions what judges told us they did with respect to consulting multiple dictionaries: they do so to determine if a word has a settled meaning and then do not rely on dictionaries if their definitions conflict. Finally, and perhaps not surprisingly, most of the judges whom we earlier called "canonists" - younger judges educated and having practiced during the rise of textualism were more forthright about consulting dictionaries both in their interviews with us and in their opinions. Even these judges, however, rarely used dictionaries to consult everyday words.

One judge may have captured it best when he said that dictionaries are useful only for "lamp-post citations" - they illuminate a point that is already in the statute. Another judge said:

Every now and then you refer to a dictionary in writing an opinion, but I've never relied on one in deciding an opinion. What gets written in the opinion is sort of a stylized version of my messier, more holistic thought process. . . I'm not trying to evade the law in what I do, but the procession in my head is much messier than what I write.

\section{The Chevron Judges: The D.C. Circuit Begins in a Different Place from Everyone Else}

All but one of our six respondents on the D.C. Circuit made clear that Chevron U.S.A. Inc. v. Natural Resources Defense Council, Inc. ${ }^{46}$ - the case in which the Court declared that reasonable agency interpretations of ambiguous statutes should receive deference from $\operatorname{courts}^{47}$ - defines their interpretive approach more than anything else. The first thing these judges think about is not what the fight is about, or what the statute is meant to do, or what the statute says, but simply

\footnotetext{
46467 U.S. 837 (I 984 ).

47 Cf. United States v. Mead Corp., 533 U.S. 218 , 226-27 (2001) (narrowing the application of Chevron deference to only those circumstances in which "it appears that Congress delegated authority to the agency generally to make rules carrying the force of law, and that the agency interpretation claiming deference was promulgated in the exercise of that authority").
} 
whether the statute invites an agency interpretation and whether the statute is ambiguous. Administrative law cases implicating these questions dominate the D.C. Circuit docket.

One judge told us that the first thing he does is to see whether the meaning of the statute is clear without interpretive aids because so finding would take him out of Cherron. Another emphasized that "the word ambiguous is a magic word in my court. It means the agency. That obviously puts pressure on the concept of what is ambiguous."

The dominance of the Chevron inquiry also makes D.C. Circuit judges less interpretively pluralistic. In response to our follow-up question on the defensibility of interpretive eclecticism, one D.C. Circuit judge said:

Judges on this court might be different from other judges because so much of our work relates to Chevron. Most cases we have on statutory interpretation if the statute is ambiguous we don't have to go further. For us, when we are reviewing statutes de novo, like in the criminal context, it's a completely different thing, in terms of your list of eclectic considerations... . But most of the time we are looking at it through the Chevron lens.

In contrast, many of the non-D.C. Circuit judges told us they did not have too much experience with Cheoron cases, or had little faith in the concept of agency deference. This difference across circuit practice is important. The decisionmaking process in a Chevron case is not the same as in a non-Chevron statutory interpretation case. As one (nonD.C. Circuit) judge aptly put it:

In the practice of Chevron, all issues come through the lens of ambiguity. If a question comes though the district court and you are without an agency, in your mind you can skip over all the anxiety about whether it is clear or not and you just come to the right conclusion. You think about the whole problem differently.

Judge Kavanaugh of the D.C. Circuit recently published an essay in which he agreed with the proposition that using the existence of ambiguity as a starting place may distort the inquiry:

[B]ecause it is so difficult to make those clarity versus ambiguity determinations in a coherent, evenhanded way, courts should reduce the number of canons of construction that depend on an initial finding of ambiguity. Instead, courts should seek the best reading of the statute . . . 48

There may be a generalizable point to make here about specialized courts. Academics have long been interested in whether specialized courts approach statutory questions differently from generalized courts. The D.C. Circuit acts essentially as a specialized court when it comes to administrative law, and our findings support the conclusion that it is not looking at cases in the same way as other appellate courts.

\footnotetext{
48 Brett M. Kavanaugh, Fixing Statutory Interpretation, I29 HARV. L. REV, 2 I I8, 2 I 2 I (20I6) (reviewing RoBERT A. KATZMANN, JUDGING STATUTES (2OI4)).
} 
Figure I: Where Judges Begin in Statutory Cases

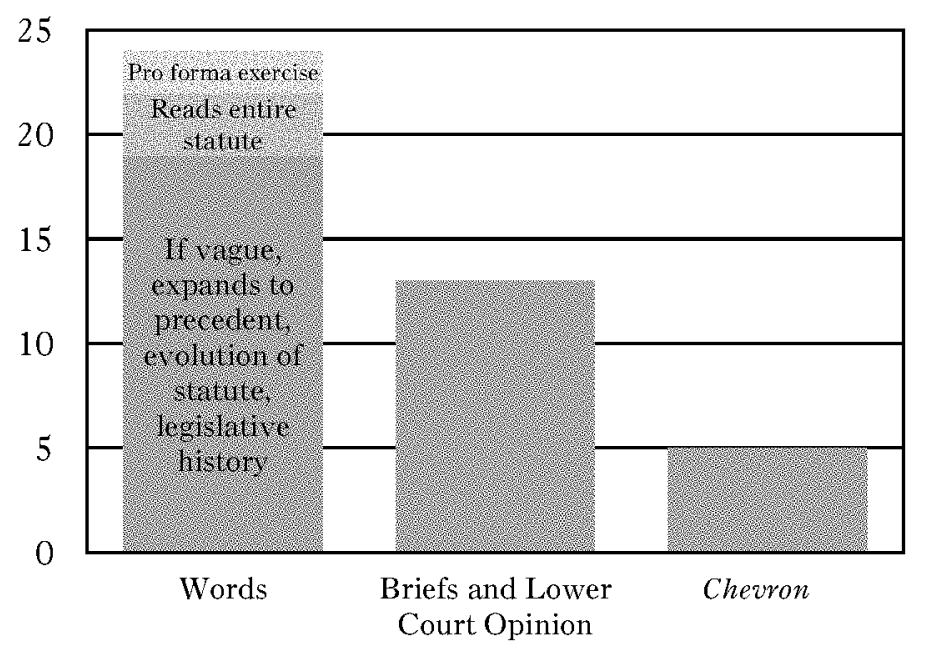

\section{EXTRINSIC SOURCES: PURPOSE, LEGISLATIVE HISTORY, AND CANONS}

The next series of questions inquired about the common extrinsic tools of statutory interpretation - legislative history, statutory purpose, and the canons of construction. The choice among these tools is the most frequently expressed reason for divisions in statutory Supreme Court cases. ${ }^{49}$ The way judges choose among these tools has also been the general method by which academics, and some judges as well, have categorized judges. ${ }^{50}$

As noted, "purposivists" are said to rely on legislative purposes and, often, legislative history. Although purposivism was once a dominant approach, textualists have been quite effective at pejoratively casting the use of purpose - especially when used to fill out or go beyond statutory text - as activist, even though there is little evidence that purpose-oriented judges are in fact more activist. ${ }^{51}$ By contrast, "textual

49 See, e.g., Lockhart v. United States, I36 S. Ct. 958, 967-68, 97 I-77 (2016) (majority and dissent disputing applicability of different grammatical canons, as well as legislative history and lenity); Abramski v. United States, I34 S. Ct. 2259, 2272 n.IO, 228I-82 (20I4) (majority and dissent disputing whether lenity canon triggered); Bond v. United States, I34 S. Ct. 2077, 2088-9 I, 209497 (20I4) (majority and concurrence disputing whether federalism canon triggered); United States v. Hayes, 555 U.S. 4I 5, 428-2 9, 434-35 (2009) (majority and dissent disagreeing on whether legislative history displaces need for canons); Babbitt v. Sweet Home Chapter of Cmtys. for a Great Or., 5I5 U.S. 687, 697-708, 7 I5-25 (I995) (majority and dissent each relying on series of different textual tools for preferred construction).

50 See, e.g., Eskridge ET AL., supra note 2, at 447-599 (differentiating among judges' approaches based on these tools).

51 See generally James J. Brudney \& Corey Ditslear, Liberal Justices' Reliance on Legislative History: Principle, Strategy, and the Scalia Effect, 29 BERKELEy J. EMP. \& LAB. L, II7 (2008) 
ists" are said to prefer plain language and canons of construction, a point highlighted by the recent Scalia/Garner treatise on the canons, which lists fifty-seven "Sound Principles of Interpretation"52 and thirteen canons that the authors call "Falsities Exposed."53 Even putting aside the Scalia/Garner work, canons are back at the forefront of academic attention, including our own. Gluck's work has pressed the question of where the canons come from (who creates them and therefore who can change them), what justifies their usage, and what role they really play in deciding cases. 54

\section{A. Judges Did Not Wish to Label Themselves as Either Textualists or Purposivists}

We saw much more agreement about the general approach than disagreement, and more emphasis on context and pragmatics than either plain text or purpose. Some of the most illuminating answers in this regard came to our question, asked toward the end of the survey, whether there was a "single word" to describe the judges' interpretive approach. We offered the descriptive terms "textualist," "purposivist," "pragmatist," "contextualist," or "anything else" as options they might choose. We provide these responses here to set the stage for the more detailed findings that follow.

Not one judge was willing to describe him or herself as a textualist without qualification. Every judge who included textualist in his or her self-description qualified the description in ways along the following lines: "some word that is on the continuum between textualist and contextualist"; "pragmatist but constraining"; "closer to textualist but not unmindful of practical consequences"; "textualist, but I would include being a contextualist"; or "textual pragmatism."

At the other extreme, only two judges out of the forty-two characterized themselves as "purposivist" without qualification (one appointed by each of the two political parties). Only four additional judges mentioned purpose at all, but with qualifications that they are both textualist and purposivist, or contextualist and purposivist. Three judges refused to answer this question, saying no single word or phrase could capture their approach. ${ }^{55}$

The figure below provides a snapshot of how judges self-described, along a continuum of textualism, to contextualism, to purposivism, to pragmatism and Chevron-oriented.

\footnotetext{
(reporting that reliance on legislative history tends to constrain liberal justices' readings of statutes in employment and labor cases).

52 SCALIA \& GARNER, supra note $\mathrm{I}_{3}$, at 47; see id. at 53-339 (analyzing each of these principles in turn).

53 Id. at 34I; see id. at 343-4 I0 (analyzing each of these falsities in turn).

54 Gluck, supra note 29, at 760-70; see also, e.g., Amy Coney Barrett, Substantive Canons and Faithful Agency, go B.U. L. REV. 109 (2010).

55 One judge was not asked this question.
} 
Figure 2: How Judges Describe Their Approach

\begin{tabular}{|c|c|}
\hline \multirow{6}{*}{$\begin{array}{c}\text { Textualist } \\
\text { I } \\
\text { I } \\
\text { I } \\
\text { Contextualist } \\
\text { I } \\
\text { I } \\
\text { I }\end{array}$} & "Narrow." \\
\hline & $\begin{array}{l}\text { "In general I'm a textualist but as Nino [Scalia] has said on occasion, } \\
\text { 'I'm not a nut." }\end{array}$ \\
\hline & "Textualist. I would include being a contextualist." \\
\hline & $\begin{array}{l}\text { "I don't think there is any difference between textualist and contex- } \\
\text { tualist; if there was it's eroded. I think that all good textualists are } \\
\text { contextualists." }\end{array}$ \\
\hline & "Contextualist." (four judges) \\
\hline & $\begin{array}{l}\text { "I would describe myself as closer to textualist but not unmindful of } \\
\text { practical consequences." }\end{array}$ \\
\hline \multirow{7}{*}{$\begin{array}{c}\text { Textualist- } \\
\text { Contextualist- } \\
\text { Pragmatist } \\
\text { I } \\
\text { I } \\
\text { I } \\
\text { Textualist- } \\
\text { Contextualist- } \\
\text { Purposive } \\
\text { I }\end{array}$} & $\begin{array}{l}\text { "Some word that is on the continuum between textualist and contex- } \\
\text { tualist, pragmatist but constraining." }\end{array}$ \\
\hline & $\begin{array}{l}\text { "I don't have a single legal philosophy. ... I am not a textualist. But } \\
\text { I don't have anything with a label. I'm not so purposivist to aban- } \\
\text { don text. If they didn't achieve their purpose then they did a lousy } \\
\text { job drafting. Too bad." }\end{array}$ \\
\hline & $\begin{array}{l}\text { "I'm probably more of a textualist than you are [referencing Posner]. } \\
\text { I would add sensible as another word." }\end{array}$ \\
\hline & "Combination of \\
\hline & "Textualist, contextualist, and purposivist." \\
\hline & "Contextualist/purposi \\
\hline & "Quasi-contextualist." \\
\hline \multirow{2}{*}{$\begin{array}{l}\text { Contextualist- } \\
\text { Purposive }\end{array}$} & "Holistic." (two judges) \\
\hline & "Diligent and thorough. I'm certainly not absolutist." \\
\hline \multirow{2}{*}{$\begin{array}{l}\mathrm{I} \\
\mathrm{I} \\
\mathrm{I} \\
\mathrm{I} \\
\mathrm{I} \\
\mathrm{I}\end{array}$} & $\begin{array}{l}\text { "To the extent any of those words reject purposivism it doesn't seem } \\
\text { right. All of those words seem to capture an important part of it but } \\
\text { I am reluctant to pick one of those terms at exclusion of others." }\end{array}$ \\
\hline & $\begin{array}{l}\text { "If textualism means I wouldn't look beyond text or dictionary, then } \\
\text { no. If purposivist means purpose above all else, then no. If prag- } \\
\text { matist means look at all the tools you have before you, then yes." }\end{array}$ \\
\hline \multirow{2}{*}{$\begin{array}{c}\text { Purposive } \\
\mid\end{array}$} & "Purposivist." \\
\hline & "Purposive." \\
\hline \multirow{3}{*}{$\begin{array}{l}1 \\
1 \\
1\end{array}$} & "Purpose with variety." \\
\hline & "Contextualist-pragmatist." \\
\hline & "Contextualist and pragmatic." \\
\hline \multirow{2}{*}{$\begin{array}{l}\text { Common } \\
\text { Sense- }\end{array}$} & "Flexible-sensible." \\
\hline & "Sensible and just." \\
\hline \multirow{2}{*}{$\begin{array}{l}\text { Pragmatist } \\
\text { I }\end{array}$} & "Pragmatist." (two judges) \\
\hline & "Realist." (two judges) \\
\hline \multirow{4}{*}{$\begin{array}{c}\mathrm{I} \\
\mathrm{I} \\
\mathrm{I} \\
\mathrm{I} \\
\text { Cherron }\end{array}$} & "Common sense." \\
\hline & "Searching for truth." \\
\hline & "Standard of review and precedent" \\
\hline & $\begin{array}{l}\text { "Begin with Chevron and precedent, then move to plain n } \\
\text { then purpose, context and structure." }\end{array}$ \\
\hline
\end{tabular}


These findings should bolster our effort to open the door to new debates in statutory interpretation because they give rise to new questions. What does it mean to be "contextualist"? Some prominent academic textualists have used the contextual label, but their reference to context often means only canons, statutory structure and surrounding words. ${ }^{56}$ Our judges took a much broader view. Pragmatism was also an important theme. Is pragmatism in statutory interpretation consistent with legislative supremacy or the role of the courts in a democracy? Are there legal doctrines that could guide interpretive pragmatism? These kinds of questions have not received the attention they deserve.

\section{B. Widespread Use of Legislative History}

Every judge we spoke with, except for one, told us he or she uses legislative history. Recognizing that we do not have a representative sample of judges, one of the most salient findings of our study is that the most common way of categorizing different judicial approaches through a judge's choice of interpretive rules and materials ${ }^{57}$ - is not a feasible sorting technique in the lower courts because it appears that many judges use all the available tools.

Most judges took a moderate approach to all of this material, and this may indeed be due to Justice Scalia's impact. For instance, judges publicly regarded as "liberal" emphasized using legislative history only in moderation, or told us that they now use it much less than they had before. As one judge put it:

I've kind of joined my conservative colleagues on legislative history. It has to be really reflective of what Congress thought and that wasn't my view earlier. I think I did get convinced by my colleagues that were hostile to it. I will use it if it's serious.

And on the other side, Justice Scalia's extreme position on legislative history was rejected by the most conservative judges on our list - including all who described themselves as the most text-centric. Instead, they all consult legislative history. Several conservative judges told us that Justice Scalia's 100\% exclusionary rule for legislative history went too far, and made comments on the order of: "I'll look at almost anything in that - committee reports, floor statements - I'm skeptical, but I most certainly will look at it"; and "Yes definitely [I use legislative history]. Discerning what the legislature meant is very hard. Today fewer judges are purposivist in the Learned Hand sense. Today we have a much smaller playing field where text is really the most important to everyone." One noted conservative judge said:

\footnotetext{
56 See John F. Manning, What Divides Textualists from Purposivists?, 106 CoLUM. L. REV. 70, 92-93 (2006) ("Textualists start with contextual evidence that goes to customary usage and habits of speech .... When contextual evidence of semantic usage points decisively in one direction, that evidence takes priority over contextual evidence that relates to questions of policy.").

57 See supra p. I 32 I.
} 
I argued with Nino [Scalia] for years about legislative history. I thought he took an extreme position. I agree to look at legislative history only if you can't discern the meaning in statutes without it. . . I don't have the same discomfort looking at committee reports, in particular the conference report, particularly if the statute was ambiguous.

Another: "The pendulum has swung too far against legislative history. Committee reports have value."

One judge explained frankly what most of us already know - even judges who may not seek out legislative history are always exposed to it through briefing materials, so it necessarily helps form an impression:

Here is where the real world departs from the theoretical world. The bench memo will have looked at the statute. Many times it will have looked at the legislative history even if the statute isn't particularly vague. It's kind of a due diligence the clerk does to prepare a judge. The suggestion that you follow some kind of methodological rule in terms of looking at legislative history tends to be overly formalist and not in the real world.

Our limited research into the opinions of the judges we interviewed confirmed that all indeed have consulted legislative history. As noted in Part I, we also randomly selected twenty-one of the judges and surveyed all of their references to legislative history in majority opinions. The median judge in that sample relied on legislative history in $32 \%$ of cases. Three of the judges relied on legislative history in more than half of statutory interpretation cases, ten in more than a third of cases, and seventeen in more than a fifth of cases.

The judges' responses to our questions also are consistent with a recent study by Brudney and Baum that looked at statutory interpretation cases across three subject matter areas in three circuits. ${ }^{58}$ That study likewise found far less disagreement among appellate judges than we see on the Supreme Court on the topic of legislative history. ${ }^{59}$ An interesting side note: Chief Justice Roberts, Justice Alito, and Justice Gorsuch all used legislative history when they were on the Courts of Appeals. ${ }^{60}$

58 Brudney \& Baum, Protean Statutory Interpretation, supra note 20

59 Id. at 7I 7-I 9 .

60 See Cook v. Rockwell Int'l Corp., 790 F.3d I088, 1096 (Ioth Cir. 2015) (Gorsuch, J.) (noting that "[a] study of the Act's history yields still more evidence [for the court's holding]"); Almond v. Unified Sch. Dist. \# 50I, 665 F.3d II74, II83 (Ioth Cir. 20II) (Gorsuch, J.) (recognizing that "[b]eyond language of [the statute] itself, [and] beyond its statutory references and history, lies the realm of legislative history," which may "serve to corroborate" textual analysis); United States v. Hinckley, 550 F.3d 926, 947 (Ioth Cir. 2008) (Gorsuch, J., concurring) ("[T]he legislative history in this case is neither murky, ambiguous, nor contradictory."), abrogated by Reynolds v. United States, 565 U.S. 432 (2012); Sierra Club v. EPA, 353 F.3d 976, 988 (D.C. Cir. 2004) (Roberts, J.) (noting that notwithstanding "superficially clear" statutory language, legislative history may be used to "shed new light on congressional intent" (quoting Nat'1 Rifle Ass'n v. Reno, 2 I6 F.3d I 22 , I 27 (D.C. Cir. 2000))); Consumer Elecs. Ass'n v. FCC, 347 F.3d 29I, 298 (D.C. Cir. 2003 ) (Roberts, J.) (noting "that we 'may examine the statute's legislative history in order to shed new light on congressional intent, 
Our findings support our view that the legislative history debate, including the idea that the use of legislative history is a litmus test for what statutory interpretation philosophy one adopts, is no longer interesting nor truly relevant and should be put to rest. We also disagree with academics who have argued that the shift in focus should be to which legislative history judges should use. ${ }^{61}$ This debate is also no debate. None of our judges told us that he or she uses legislative history indiscriminately. Each one emphasized an informal hierarchy of legislative materials, with committee and conference reports generally at the top, as most congressional experts recommend. ${ }^{62}$ Indeed, perhaps due to the effect of developments in legal education on the younger cohort of judges, one such judge told us: "Legislative history, it's another thing for better or worse that I have been instructed about. I have been instructed floor statements are weaker and committee reports and congressional conference reports are strongest."

This is not to say that judges always get it right. The GluckBressman empirical study of the legislative process found certain kinds of legislative history - for instance, committee markups and consensus, bipartisan history - particularly valuable. ${ }^{63}$ It did not seem to us that the judges we spoke with were making determinations of reliability at that level of specificity. But they seemed receptive to being educated about which materials were more reliable and relevant to any particular case. We think this is an important role to be played by lawyers in the briefings.

notwithstanding statutory language that appears superficially clear'" (quoting Nat'l Rifle Ass'n, 2 I 6 F.3d at I 27 )); id. at 297 ("To determine whether Congress has . . . spoken [to the precise question at issue], we apply 'traditional tools of statutory interpretation - text, structure, purpose, and legislative history." (quoting Pharm. Research \& Mfrs. of Am. v. Thompson, 25 I F.3d 2 I9, 224 (D.C. Cir. 200I))); Confirmation Hearing on the Nomination of John G. Roberts, Jr. to Be Chief Justice of the United States: Hearing Before the S. Comm. on the Judiciary, Iogth Cong. 3 I9 (2005) (statement of Judge John G. Roberts, Jr.) ("I have, though, as a judge, relied on legislative history to help clarify ambiguity in the text. ... I have quoted and looked to legislative history in the past to help determine the meaning of ambiguous terms, and I would expect to follow that same approach on the Supreme Court."); Elliot M. Davis, Note, The Newer Textualism: Justice Alito's Statutory Interpretation, 30 HARV. J.L. \& PUB. POL'Y 983, 983-85, 992-93 (2007) (claiming that Justice Alito consulted legislative history to establish the appropriate context in which to read statutory text usually when the statute's language was not dispositive, but also occasionally when it was unambiguous).

61 See, e.g., Victoria F. Nourse, A Decision Theory of Statutory Interpretation: Legislative History by the Rules, I22 YALE L.J. 70, 76-77 (2012) (offering rules for deciding which legislative history to use); see also James J. Brudney, Below the Surface: Comparing Legislative History Usage by the House of Lords and the Supreme Court, 85 WASH. U. L. REV. I, 63 (2007) (advocating a move away from debate about exclusion of legislative history and instead to one about its relative weight).

62 See, e.g., Nourse, supra note 6I, at 98 .

63 Gluck \& Bressman, Part I, supra note 7, at 978, 986-88. 


\section{Almost All Judges Invoked Purpose}

Purpose seems to be another straw man, relevant only to academic (and perhaps artificial) divisions in the Court. Only four of the fortytwo judges we spoke with did not mention purpose as an appropriate tool of statutory interpretation. ${ }^{64}$ The judges we spoke with interpreted the search for purpose in terms of "the mischief" or "the problem that gave rise to the statute in the first place." One described it as follows: "What are they trying to accomplish? Absolutely I use it."

No judge advocated the so-called sin of the Holy Trinity (referring to the infamous and much-maligned I 892 decision that first sanctioned using a statute's "spirit" to trump clear text). ${ }^{65}$ Holy Trinity has long been used as a foil by textualists to argue that textualism offers a more objective approach. But the judges with whom we spoke use purpose as part of the background context, together with other evidence, including text.

\section{Canons of Construction}

The canons of statutory construction, like the use of legislative history, have been held out as a type of judicial-philosophy litmus test. To the extent that the field of legislation has "doctrines," they are the canons. ${ }^{66}$ The canons include presumptions about language use (for instance, the presumption that terms are used consistently throughout statutes, or the presumption that Congress does not use repetitive language) and presumptions about policy (for instance, the presumption that federal statutes do not preempt state law unless they clearly so state, or the presumption against extraterritorial application of statutes ${ }^{67}$ ). Some canons, like the rule of lenity, date back centuries. ${ }^{68}$ Others, like the federalism canon, are creations of the modern Court. ${ }^{69}$ Together with textual arguments and legislative history, the canons comprise the basic advocacy toolkit for statutory cases. These presumptions are the subject of an increasing number of law school courses as well as of the

64 One judge was not asked the question.

65 Church of the Holy Trinity v. United States, I43 U.S. 457,459 (I892) ("It is a familiar rule, that a thing may be within the letter of the statute and yet not within the statute, because not within its spirit, nor within the intention of its makers."). This is the case most reviled by textualists for its purpose-over-text approach. See Zuni Pub. Sch. Dist. No. 89 v. Dep't of Educ., 550 U.S. 8 I, I I6 (2007) (Scalia, J., dissenting) (referring to Holy Trinity as "that miraculous redeemer of lost causes").

66 See ESKRIDGE ET AL., supra note 2, at 447 (calling the canons the "doctrines of statutory interpretation").

67 See, e.g., Morrison v. Nat'l Austl. Bank Ltd., 561 U.S. 247,255 (2010).

68 See, e.g., Johnson v. United States, I35 S. Ct. 255 I, 2567 (2015) (Thomas, J., concurring in the judgment) ("This rule of construction — better known today as the rule of lenity — first emerged in I6th-century England ....").

69 See, e.g., Gregory v. Ashcroft, 50I U.S. 452, 460-61 (I991). 
Scalia/Garner treatise. ${ }^{70}$ As one judge put it: "[T]hese are typically in the arguments advanced by counsel on one side or other, so that certainly brings me to take them into account . . . Scalia and Garner's book cites sixty-plus of them. [Professor] Eskridge provided a list too." 1

It is sometimes assumed that purposivist judges use legislative history, while textualist judges use canons. That assumption should be put to rest. All of our forty-two judges use both tools to some extent and there does not seem to be any link between their canon use and the political party of their nominating Presidents, or their denominations as conservative or liberal.

This is not to say that the canons are treated as "law," as ordinary doctrine is, or that their legal status is even fully understood. ${ }^{72}$ The Court itself has called them mere "rules of thumb." 73 Judges across the board generally do not give the canons precedential effect. And yet, the canons dominate briefing in cases raising statutory interpretation questions and are typically referenced in opinions to justify statutory interpretation decisions. A random sampling of opinions from each of the forty-two judges we interviewed revealed all of the judges to use canons routinely, despite some telling us that they do not.

At least since Professor Karl Llewellyn's famous exposition in $1950,{ }^{74}$ canons have always been part of the intellectual debate over statutory interpretation. Are there too many? Are they simply tools for post-hoc justification of what is really result-oriented judging? In addition to these questions, which have been percolating for some time, in recent years academics have raised new jurisprudential questions about the canons. These new questions include inquiries about the canons' sources - that is, where do they come from (judges? Congress? the Constitution?) - and, relatedly, about who can alter them. ${ }^{75}$ Such inquiries are important, because they relate to the judicial lawmaking power in the statutory era and also the extent of Congress's authority over the interpretive methods judges use.

Another set of inquiries goes to the canons' purpose and whether they are fulfilling that purpose. For instance, if the canons are supposed

\footnotetext{
70 See SCALIA \& GARNER, supra note I3; Gluck, supra note 2, at I 57.

71 For the Eskridge appendices listing the canons, see EskRIDGE, GLUCK \& NoURsE, supra note 2, app. 6, at IOgI-II4; and William N. Eskridge, Jr. \& Philip P. Frickey, The Supreme Court, I993 Term - Foreword: Law as Equilibrium, I08 HARV. L. REV, 26 app. at 97-I08 (I994).

72 See Gluck, supra note I9, at I909-I8 (detailing the ambiguous legal status of federal statutory interpretation methodology).

73 Conn. Nat'l Bank v. Germain, 503 U.S. 249, 253 (I992).

74 Karl N. Llewellyn, Remarks on the Theory of Appellate Decision and the Rules or Canons About How Statutes Are to Be Construed, 3 VAND. L. REv. 395, 40I-06 (I950) (showing that for every canon there is a counter-canon).

75 See generally Barrett, supra note 54; Gluck, supra note 29; Nicholas Quinn Rosenkranz, Federal Rules of Statutory Interpretation, II5 HARV, L, REV, 2085 (2002).
} 
to be presumptions that Congress knows or shares, as courts often claim, ${ }^{76}$ it seems important to verify them as such. If, alternatively, canons aim to affect how Congress drafts, as courts claim also - for instance, making Congress draft with more precise language or with certain policy norms in mind ${ }^{77}$ - then it would be important to confirm that they do actually serve those purposes. If canons aim simply to reflect congressional drafting practice, ${ }^{78}$ likewise it matters if they actually do. Gluck's empirical work calls all of these sets of assumptions into doubt. ${ }^{79}$ And if canons are instead policy norms that judges apply atop Congress's work product, then we should press for reasons why judges think that this kind of quasi-legislating is legitimate, and determine whether they even acknowledge it as such.

Even though the judges we interviewed certainly use canons, their reasons for doing so did not approach anything close to this level of analysis. The notion that the canons may need a connection to how statutory language works to be legitimate did not seem a concern for most of the judges (with a few exceptions); nor did the judges recognize canons as judge-made policy. Most judges also did not seem to appreciate that learning about the legislative process might debunk certain canons from common usage (for instance, why apply the rule against superfluities if legislative drafters are often intentionally redundant? ${ }^{80}$ ). At the same time, the judges we spoke with had no other articulated reason for why they would use the canons, even if they did not reflect congressional understanding or practice. This is not to say there might not be such justifications; ${ }^{81}$ simply that none was offered.

While these results were not surprising, they are disappointing, given the heavy use of the canons by lawyers and even these same judges. Is the mere fact that canons may provide a common language for parties in the legal system to talk about statutory cases enough to justify their use, even if judges do not really have a justification for which ones are used and why? One of us (Posner) thinks emphatically "no."

76 See, e.g., Lockhart v. United States, 546 U.S. I 42, I 48 (2005) (Scalia, J., concurring) ("[L]egislative express-reference or express-statement requirements may function as background canons of interpretation of which Congress is presumptively aware."); AT\&T Corp. v. Iowa Utils. Bd., 525 U.S. 366,397 (I 999) ("Congress is well aware that the ambiguities it chooses to produce in a statute will be resolved by the implementing agency." (citation omitted)); Associated Gen. Contractors of Cal., Inc. v. Cal. State Council of Carpenters, 459 U.S. 5 I 9, 53 I n.22 (Ig83) ("Congress . . . appear[s] to have been generally aware that the statute would be construed by common-law courts in accordance with traditional canons.").

77 Gluck \& Bressman, Part I, supra note 7 , at 9I3-I6 (laying out the different justifications courts have used for applying the various canons).

78 See $i d$. at 9o6-07.

79 See id. at 907 .

80 See Loving v. IRS, 742 F.3 IOI3, IOI9 (D.C. Cir. 2014) (Kavanaugh, J.) (refusing to apply the rule against superfluities because it makes unrealistic assumptions about congressional drafting).

81 For instance, textual canons might serve notice values, or policy canons might serve constitutional values. 
We also asked judges about their practice of citing canons in opinions. The judges' answers to this question fell into three categories: (I) the canons help explain outcomes for purposes of opinion writing but do no real work; (2) they are helpful "guideposts" when deciding cases; and (3) judges apply certain canons, without evaluation, because the Supreme Court has so commanded. We asked about the "linguistic" or "textual" canons, which are presumptions about how language is used (for example, ejusdem generis is the concept that the meaning of a general term in a list should be construed in accordance with more specific terms in the list, and expressio unius is the concept that the inclusion or exclusion of express statutory terms presumes the intentional exclusion or inclusion of others). We also asked about the "substantive" or "policy" canons, which are normative presumptions (such as the rule of lenity, which provides that courts construe ambiguous criminal statutes in favor of defendants; or the presumption against preemption of state law; or the canon of avoiding constitutional questions).

I. Canons as Tools of Persuasion, Not Decision. - "Like an Old Song." - Roughly one third of the judges told us that the canons are "tools to make your arguments more persuasive or to persuade colleagues." For these judges, the canons are primarily tools of opinion writing. Linguistic canons especially, as opposed to policy canons, seem to be of this "window dressing" variety. Eight judges made a comment on the order of:

Linguistic canons, to be honest, I use after I have made up my mind to help draft the opinion. It's a good argument after the fact. If it fits the bill, even if it is not central to my thinking, if I think it will help someone else organize their thoughts I will throw it in.

Or: "I don't think at [the canon] level when reading but when I'm writing the opinion I have to start explaining why we are doing it. . . . When I have to write a cogent, intellectual-sounding defense I use them." Judges of all generations and political parties made similar statements.

One judge put it this way:

[Opinions] make law but they also help persuade people that this is the correct reading and so when they get a chance to make a decision they should follow it. So the canons among other things are like talking to other players in the process. Talking to other judges, to other circuits. The canons of construction add one more layer to the advocacy of an opinion. All of this may be unnecessary to the party but there is a sort of coordination that happens across the judiciary and canons tend to be persuasive.

Another told us that "sometimes they are helpful in explaining. It's like an old song."

2. Canons as Useful Decision Tools, Planted in the Judge's Mind. Twenty-six judges, including some who also said that the canons were useful for opinion-writing purposes, reported at least some canons to be genuinely useful to their decisionmaking processes. Several of the younger judges seemed to realize that they referenced the canons almost 
unconsciously, largely because they were educated about them in law school. One of these judges told us that he uses canons because he "feel[s] obliged to use them," thanks to learning them in law school as the field's doctrines. This, he explained, has both made him view the canons as "a tool you have to deploy" and also shaped his thinking about statutes in ways that cannot be consciously undone: "I try to think about what [a statute] means and these things [canons] are popping into my mind. If I had been educated differently maybe other things would pop into my mind. I can't help it." Another younger judge told us that as a practicing lawyer, statutory cases were his favorite cases to "brief and argue because I liked the fact there was a relatively closed set of tools and cases to work through. It was like a puzzle." Another told us she had been given a list of the canons "at baby judge school" and kept them on her desk her first few years on the bench. In her view, the canons are "helpful to cabin our role and limit our discretion. Yes, I do think they help make decisions."

The Gluck-Bressman empirical study of congressional drafting suggests that there may be a difference in canon awareness between younger legislative drafters and older ones. ${ }^{82}$ Similarly, there appears to be a generational effect among the judges we interviewed with respect to how entrenched the canons are in their thinking that tracks the dramatic rise of legislation courses in law schools over the past three decades.

One younger judge in this category embraced canons for rule-of-law reasons; he found that neutral rules help broker consensus among judges. "The reason I like them," he said, "is that if we use them it's a way of finding rules for things when we decide the cases. It's a way of being objective.... It allows judges of different ideological stripes to decide cases."

But most of the judges viewed the canons as "guidelines that are helpful." As one judge put it: "They are reminders of what I think intuitively is the answer anyway." Another described them as a tool "that reinforces a conclusion." This reminder function does not seem insignificant. For instance, if the mere existence of the federalism canon has conditioned judges to think about federalism in any case where a federalism question could present, then the canons have not done nothing. The policy and constitutional canons in particular may be serving as something of a checklist of norms that judges now intuitively consult in statutory cases.

3. Lenity and Avoidance Are Special. - Some canons seem special. Thirteen judges - some of whom find most canons useful only as posthoc window dressing and some of whom find canons more generally useful — singled out lenity and/or constitutional avoidance as "actual

\footnotetext{
82 Gluck \& Bressman, Part I, supra note 7 , at 1022 (suggesting the "possibility that drafter awareness of the canons is generational and is changing across time").
} 
rules" and distinguished them from the other canons, in terms of their mandatory application. They told us that these presumptions are "not canons" but rather are "substantive law." Some judges seemed to believe these doctrines derived their special status simply because the Supreme Court said they did. (This observation, to us, implies a view that the Supreme Court could designate more canons to have this special status. Nevertheless, and inconsistent with this observation, many of these same judges later told us that the Supreme Court could not control lower-court interpretive methodology when we asked that question.) A few judges did not see these canons as deriving their power from the Supreme Court, but rather from the Constitution (for example, that lenity derives from the constitutional concept that federal judges cannot create crimes).

4. Canons in Opinions. - Many canons other than lenity and avoidance permeate judicial opinions, regardless of what judges say about them. There are some useful observations to draw from this. First, we think the role of the lawyers and the law clerks with respect to canon citation practice cannot be overstated. As one judge told us:

Often [judges] get a bench memo and the bench memo cites canons. They may be taken from the briefs. But then by the time they get to conference I can't remember anyone using canons to justify their vote, but they will end up in the opinion. Why? I don't know. Maybe [judges] go back to the bench memos.

If lawyers and law clerks argue in canons, judges who draw on briefs or law-clerk work for opinion writing may be referencing canons in their decisions too, even if those canons did not actually inform the judges decisions.

We also think that the framing role that lawyers play in making salient the key canons for each case has been underappreciated. As noted, our random study of opinions from the judges we interviewed revealed that many canons used in the opinions were introduced by the briefs. Professor William Eskridge and Lauren Baer have similarly demonstrated, in the administrative deference context, that the Court relies heavily - sometimes quite literally — on the rationales provided in the briefing in applying the deference canons (for instance, Chevron, Skidmore, ${ }^{83}$ or Curtiss-Wright ${ }^{84}$ ) and that the regime chosen generally defines the case. ${ }^{85}$

\footnotetext{
83 Skidmore v. Swift \& Co., 323 U.S. I34, I40 (I944) (affording agencies' interpretations weight in accordance with their "power to persuade").

84 United States v. Curtiss-Wright Exp. Corp., 299 U.S. 304, 329 (I936) (affording especially strong deference to the Executive's interpretation of a statute related to matters involving foreign affairs).

85 William N. Eskridge, Jr. \& Lauren E. Baer, The Continuum of Deference: Supreme Court Treatment of Agency Statutory Interpretations from Chevron to Hamdan, 96 GEO. L.J. I083, I I3644 (2008).
} 
There is something to be said here, too, about what seems to be the impact of the exercise of opinion writing in this context. The values that underlie judicial reason giving are well-trod scholarly ground. Scholars and judges have argued that reason giving is central to judicial legitimacy. ${ }^{86}$ Posner, among others, suggests that judicial reason giving enhances accuracy and principled adjudication by forcing judges to articulate their decisionmaking process and thereby ensure that decisions are not arrived at arbitrarily. ${ }^{87}$ Still others argue that reason giving educates the public as to the workings of the law and makes law more predictable. ${ }^{88}$ But when it comes to the use of reasons - especially the canons - in statutory interpretation opinions, the reason giving process seems, at best, only weakly tied to any of the above justifications. Because the canons themselves may not be real reasons that the judge relies on in deciding, or to which he or she even generally commits, using them to make opinions merely seem more legitimate and more lawlike to colleagues or the public does not further reason giving's traditional goals.

Some have argued that judicial reason giving serves an analogous role to precedent - a commitment to broader principles and a source of constraint. ${ }^{89}$ There may be something to the fact that, in the absence of a system of methodological precedent, ${ }^{90}$ canons do fill a void where citation to precedent in other types of opinions would be more typical. ${ }^{91}$ Another explanation may be that using canons to justify opinions that are, in fact, based on a much broader array of considerations, including common sense, provides cover to judges who are insecure about otherwise embracing pragmatic, common law-type reasoning they wish to employ in a field that is ostensibly guided by principles of legislative supremacy. We are not the first to note that insecurity. ${ }^{92}$ But why judges feel it is a subject that has yet to be deeply considered.

\footnotetext{
86 E.g., Micah Schwartzman, Essay, Judicial Sincerity, 94 VA. L. REV. 987, I004 (2008) ("IT]he principle of legal justification is based on the idea that legal and political authorities act legitimately only if they have reasons that those subject to them can, in principle, understand and accept."); Patricia M. Wald, The Rhetoric of Results and the Results of Rhetoric: Judicial Writings, $62 \mathrm{U}$. CHI. L. REV, I37I, I372 (I995).

87 See, e.g., Richard A. Posner, Judges' Writing Styles (And Do They Matter?), 62 U. CHI, L. REV. I42 I, I447 (I995) ("In thinking about a case, a judge might come to a definite conclusion yet find the conclusion indefensible when he tries to write an opinion explaining and justifying it.").

88 E.g., Schwartzman, supra note 86, at 1008-10.

89 See Frederick Schauer, Giving Reasons, 47 StAN. L. REv, 633, 656-57 (I995).

90 See infra Part VI, pp. I343-47.

91 Cf. Jonathan Macey \& Geoffrey P. Miller, The Canons of Statutory Construction and Judicial Preferences, 45 VAND. L. REV. 647, 660 (I992) ("With the modern statutorification of law, canons increasingly serve the same alternative function as precedent does in the weak form of stare decisis.").

92 Eskridge and Professor Philip Frickey noted this insecurity many years ago. See Eskridge \& Frickey, supra note 37 , at 364 ("These two observations - the Court's tendency to overstate arguments supporting its results and to understate the importance of evolutive factors - are related to
} 
What came across most saliently was that the judges we interviewed had not thought deeply about the canons they deploy and why they deploy them. Even though most judges told us they were not bound to use canons, and many disparaged them, all use them.

\section{RELATIONSHIP WITH THE LEGISLATURE AND ROLE OF THE JUDGE}

A different way to approach the question of why judges adopt the interpretive methods they do is to inquire about their views of the judicial relationship to Congress. We asked the judges whether they thought that understanding more about how Congress works would be relevant to their interpretive processes. We offered, as an example, whether knowing that a statute was drafted in different parts by multiple congressional committees that did not communicate with one another (a not uncommon occurrence in the real world ${ }^{93}$ ) would defeat the oftenapplied presumption of consistent usage - one of Scalia/Garner's "most favored" presumptions. ${ }^{94}$

We also asked the judges about the extent to which they see the judicial role vis-à-vis statutes as reparative, punitive, pragmatic, updating, or none of these. And we asked whether they try to make statutory language consistent regardless of whether they think Congress is trying to be consistent. Many of the canons impose this kind of coherence on statutes, and we had many judges both telling us that they themselves use these canons but then, in answers to other questions, emphasizing that judges must take statutes as they find them - that is, that they do not see their role as improving on Congress's work.

We did not find those perspectives to be consistent with one another. Cohering a text that is not coherent at the outset is a version of improving on Congress's work. Justice Scalia himself never acknowledged coherence as improvement, either, even as textualists maligned purposivists for their view of courts as Congress's partners.

We also asked the judges whether they interpret statutes in ways different from a textual reading to avoid absurd results and whether, when confronting issues that Congress did not foresee, they try to make statutes as sensible as possible or sometimes update them. We found most judges willing to interpret around absurdities, and some who were willing to update statutes, even though some of these judges had told us

one another, and related to what must be the primary reason for the continuing appeal of foundationalist theories of statutory interpretation: The Court remains insecure in the legitimacy of its statutory interpretations. To justify such interstitial lawmaking, the Court feels it must establish a compelling case for the interpretation based upon 'objective' evidence . . ..").

93 See Gluck \& Bressman, Part I, supra note 7, at 936-37; Gluck \& Bressman, Part II, supra note 7 , at 793 .

94 SCALIA \& GARNER, supra note I3, at I 70-73. 
in answers to other questions that we asked that it was not their job to help Congress.

\section{A. Value of Understanding Congress}

All but seven of the judges we interviewed told us that understanding Congress is valuable for statutory interpretation. Many of these judges had experience working on Capitol Hill earlier in their careers. They told us that this background informed their views and gave them a comfort level in working with statutes. For example, one judge commented, "I feel I have a good insight on how the legislative process works and it is helpful. By contrast, I don't know squat on how the legislative process works [in the state capital] . . . . So when I get a question about state legislation I feel less certain ...." Several judges mentioned the idea of a Federal Judicial Center (FJC) training program on the legislative process for judges.

Yet, in another puzzle, even among the judges with an interest in how Congress works and a belief that such information is relevant to the task of judging, very few had ever considered examples like the one we raised (about not applying the presumption of consistency to statutes drafted by multiple noncoordinating drafters), or had thought much about applying knowledge of the legislative process to evaluating other legislative presumptions. ${ }^{95}$ As one judge put it:

I have been around a long time. I understand how Congress works. I have yet to see anyone argue something like the words in different statutes passed at different times by different committees aren't used consistently. It would be interesting to have that issue litigated. I have never seen anyone arguing that way about how Congress really works.

Another judge noted, "Yes, [a better understanding of the legislative process] would be helpful. We have opinions saying the presumption about consistent term usage is rebuttable, but we don't have any opinions saying it's rebuttable because of how Congress works."

Puzzlingly, a handful of judges told us they were interested in how Congress works specifically (and it seems only) because they thought it helped debunk the case for legislative history. As the Gluck-Bressman study illustrated, however, congressional drafters from both parties tend to insist that legislative history is essential to understanding statutes. ${ }^{96}$ It is thus ironic that some of the judges told us that understanding Congress is useful only to make the case against legislative materials.

95 From the view of one judge who had thought about this question:

Knowing something about the legislative process is helpful. I don't agree with the whole act rule - that canon strikes me as particularly wacky. Statutes get amended dozens of times by numerous different political coalitions. It's so long no one can figure out what's in it. The idea that something put in the act in 1976 should be read the same way if it uses the same language if that language is put in thirty years later, is ludicrous.

96 Gluck \& Bressman, Part I, supra note 7 , at 965 . 
None of the judges who reported this interest also told us that understanding Congress could shed light on other interpretive questions or the applicability of widely accepted canons, like presumptions of statutory perfection, that are not linked to how Congress actually drafts.

Previous legislative experience may be more relevant to a judge's general - often more forgiving - approach to statutes than to his or her use of specific canons. Those with Capitol Hill experience emphasized how the practical understandings that come from knowing how Congress works help with statutory interpretation cases. One judge explained:

You can't answer everything in a statute. You can see all of this in the U.C.C. Originally there were fifty-nine provisions. Now there are I Ig. They are trying to answer all the questions but you can't. The codes get longer and longer and longer. When that happens, when the statute is vague, you have to work it out. You never say that we are doing the drafting but, in some ways, you become a shadow legislator. You have to supply the answer. We say we are doing interpretation and we aren't trying to be activist but you become a shadow legislator.

Understanding that statutes cannot cover every situation gives this judge a sense of his role as "shadow legislator"; it legitimizes to his mind the judge's gap-filling function. Another judge of the younger generation said that her Capitol Hill experience made her skeptical about statutory interpretation tools that assume legislative perfection or omniscience:

I am no master of the intricacies about how Congress works but I do have a healthy understanding. You need to understand there is a slapdash quality to what happens. You should not expect a level of precision in statutes that isn't there. It is a healthy understanding to have to understand stuff that comes out of the process. No one has thought so much about comma placement, etc.

These sentiments were echoed by a judge of the older generation who also worked on the Hill:

I think the public thinks that the process of statutory interpretation is much easier than it actually is and that judges should have a much smaller role. But Congress has its own problems in drafting. That is difficult. It is almost an impossible task to cover the waterfront and have it work forever. Sometimes there is a disconnect between what the Court thinks and the processes of what judges are doing. Scalia's idea of legislative supremacy and judges just trying to carry out known directives is just not the fact.

Another judge agreed that understanding more about Congress could assist appellate judges because briefs in the courts of appeals are not always sufficiently sophisticated to tell the complex story of how statutes are put together. "Maybe by the time you get to the Supreme Court you have various amicus briefs," he said, "but it is useful to know about the legislative process. Why a statute looks the way it does." 
Four judges expressed no interest at all in how Congress works. Two other judges thought it would just be too difficult for judges to use such knowledge. They argued that the process would be "essentially impenetrable by judges"; that "interpreting in light of a realistic understanding of how legislative 'sausage' is made would somehow invade legislative prerogatives, as well as confuse judges." Another judge, in response to the information about how multiple committee drafters defeat assumptions of consistency, said:

For me that's a "whoa" moment, but if judges start worrying about that we are asking for trouble. It's the statute that's enacted and we have to live with it. It's a terrible mistake if we start fooling around with that info. Congress has got to understand how we are going to operate even if these assumptions are fictitious.

Another said, "we'll always be amateurs." One judge referred to the arguments by textualists that statutes are made up of impenetrable compromises. ${ }^{97}$ As a result, "learning the process won't help judges with that essential problem of not being able to get into the statutory deals," he said. "All you can do is look at the text agreed on. I agree with John Manning on this." 98

I. Modest Interventions. - One recommendation, which we have noted was made by several judges, is an FJC program to train judges on the legislative process. We note that several appellate judges - not necessarily included in our survey - already have tried to incorporate real-world understandings of how Congress works into their opinion writing. Both Justice Elena Kagan and D.C. Circuit Judge Brett Kavanaugh recently have cast doubt on the well-worn "rule against superfluities" - the presumption that statutes are drafted without redundancies - in light of empirical evidence that congressional drafters are often redundant - sometimes carelessly but frequently on purpose. ${ }^{99}$ Judge Karen LeCraft Henderson, also on the D.C. Circuit, recently cited empirical work to argue that courts should not ignore legislative history in determining the extent of an agency's discretion. ${ }^{100}$ And Second Circuit Chief Judge Robert Katzmann has been arguing for many years for greater incorporation of knowledge about the legislative process into statutory interpretation doctrine. ${ }^{101}$

97 See, e.g., Frank H. Easterbrook, Statutes' Domains, 50 U. CHI. L. REV. 533, 540-4I (I983).

98 See, e.g., Manning, supra note $\mathrm{I} 4$, at 430-3 I (discussing the difficulty of ascertaining congressional intent in the context of legislative bargains).

99 Yates v. United States, I35 S. Ct. I074, 1095-97 (2015) (Kagan, J., dissenting); Loving v. IRS, 742 F.3d Ior3, Iorg (D.C. Cir. 2014).

100 Council for Urological Interests v. Burwell, 790 F.3d 2 I2, 233 (D.C. Cir. 2015) (Henderson, J., dissenting in part) (citing empirical work, Gluck \& Bressman, Part I, supra note 7 for the proposition that legislative hitory can be used at Chevron Step One to disambiguate statutory text because "Congress often uses legislative history," rather than the text, to restrain agencies in the exercise of their delegated authority).

101 KATZMANN, supra note 48 , at $48-49$. 
Focusing on only the judges, however, may be a weak strategy. It is not clear whether judges would affirmatively seek to apply such information once learned, or whether information about the congressional process would enter cases only if and when lawyers bring it in. It seemed to us that many of these judges would be receptive to arguments in legal briefs that bring information about congressional process to bear on specific arguments about statutory interpretation, whether about canons or the most relevant legislative history. As we have noted, canons are most often introduced by the lawyers in framing and briefing cases, and then those same canons are taken by the judges in opinion writing. Education of the practicing bar about the legislative process might therefore have a significant effect on how canons are ultimately used in opinions. Further, given the apparent influence of recent trends in legal education on at least some of the judges we surveyed, we also believe that more sophisticated law school courses in legislation and legislative process - courses that do more than merely teach the doctrines but also critique and situate them in the context of real-world lawmaking - could have a salutary effect.

\section{B. Imposing Consistency on Statutes}

We also asked the judges whether they would impose consistency and coherence on statutes even if they knew Congress had not. We asked this question for two reasons. First, imposing consistency and coherence on statutory language is the goal of many of the canons of interpretation, and we were curious whether judges who told us they deployed textual canons viewed them in this way. Second, a common criticism of the use of purpose, legislative history, or pragmatism as interpretive tools is that those methods are "activist," but so is imposing coherence on statutory language where Congress itself did not impose such coherence.

I. Do Not Impose Consistency Where Congress Did Not. - Of the thirty-seven judges asked this question, ${ }^{102}$ eleven told us that they do not or only rarely interpret statutes to make them more consistent or coherent. Our random sample of the opinions of all judges interviewed, however, illustrated that, at least in opinion writing, all of the judges we interviewed used the cohering or coherence canons at least some of the time. In applying these canons, it may be the case that judges do not realize that they are imposing presumptions that Congress itself does not impose.

Across the eleven who generally disfavored the coherence canons, there were three kinds of responses. Some judges said they reject these principles because they wish to stay true to what Congress wrote. They told us, "I don't want to impose a fake reading" or "I just try to get the

102 Five were not asked this question. 
statute a fair reading." Some judges said they were "wary of doing something Congress didn't do," especially if it could upset a legislative compromise. Others took a tough-love approach to Congress, saying, "statutes are a mess; we shouldn't clean them up" and "I really despise the idea that we should make the statutes better." Others described the consistency principle as a weak norm, only to be used where it really makes sense. For instance: "It might make sense in different statutes closely enacted like the securities statutes, but I would not go further than that to cohere statutes."

2. Imposing Consistency and Coherence Even Where Congress Has Not Is "Part of the . . Judicial Function." - In contrast, twenty-three of the thirty-seven judges who were asked this question told us that imposing consistency and coherence on statutes "is part of our job. ... It [is] the judicial function." These judges were nearly equally split across political party of the appointing President. Many emphasized that this aspect of their interpretive work is about ensuring that statutes give proper notice to the public - it is not necessarily about reflecting Congress: "It is a good thing to impose coherence. It is unfair to ask the reader to see terms of the statute differently." Another emphasized "the importance of consistency to judges and the public's trust in what we do. These are all factors that come into the judicial thinking on this." One noted textualist told us: "I do like the fact that Scalia and Garner says we don't presume that Congress knows everything but we act as though they did because it is better to save than destroy."

Most of the judges who answered in this vein did not associate this cohering or reparative function with any kind of judicial activism or judicial lawmaking. One rare comment (from a Republican appointee) was: "I think this is usually our human nature. Try to get something internally consistent, trying to make something rational that no one thought about at the time. You become, whether you like it or not, a mini-legislator."103 Another (Democrat-appointed) judge said:

I take your point and I realize we are idealizing the legislature and saying

it legislates in a coherent way when it doesn't. That's true but without those canons, but just in terms of the functioning of the judiciary and its legitimacy in the eyes of the public I think there is an important role for those kinds of canons.

That approach differs from how the Supreme Court normally talks about its statutory interpretation work — both in the sense of the judicial function identified and in the candor and reflection about the work. The idea that our common law judges view their role as guarding or even improving on the integrity of the statutory code is not a conception

\footnotetext{
103 Two additional judges made observations about Congress that did not fit neatly into the categories described.
} 
of the judicial role that is closely associated with any of the dominant theories of interpretation. Indeed, one of us has pointed out elsewhere that this way of judging finds interesting parallels in aspects of civilcode judging, where achieving statutory coherence through interpretation is often a central function of the judicial role. ${ }^{104}$ The focus on the code's integrity also has relevance for our updating question, discussed below.

\section{Interpretation to Avoid Absurdity, to Advance Common Sense, or to Update}

This line of inquiry concluded with a question about whether judges "try to make a vague or ambiguous statute as sensible as possible," and another question about whether they ever apply the so-called "rule against absurdities," under which judges depart from the text to avoid absurd results. In our follow-up questions, we inquired whether judges see it as within their role to update a statute's language to fit modern applications that were unforeseen (and might have been rejected even if considered) by the enacting Congress. ${ }^{105}$

Nine judges were strongly against using a pragmatic approach to address statutory ambiguities. One of these judges told us that if a statute was so vague that a judge had only his common sense to resort to, he should "strike the statute down." (We note this almost never actually happens in statutory interpretation cases. Judges almost always address issues of vagueness by giving the statute a narrowing construction, rather than invalidating it. ${ }^{106}$ ) The other eight judges voiced their opposition to "cleaning up" Congress's "mess" or "improving" statutes, even though all of these judges would apply the rule against absurdities to avoid a truly absurd result, and also the "scrivener's error" rule to correct a typographical or grammatical error. This stance is somewhat puzzling to us, given these judges' disavowal of pragmatism. Manning observed long ago that the rule against absurdities is inconsistent with textualism. ${ }^{107}$

The judges we interviewed may be taking their cues from the current Court, which has often purported to adopt this stingy approach to correcting mistakes. For our part, however, we do not see, as a matter of

\footnotetext{
104 Abbe R. Gluck (forthcoming) (manuscript not yet titled) (research on file with author). Interestingly, in modern practice civil-code judges may now be more liberal interpreters than American common law judges. See id.

105 See, e.g., Hively v. Ivy Tech Cmty. Coll., 853 F.3d 339, 352-57 (7th Cir. 20I 7) (en banc) (Posner, J., concurring).

106 See, e.g., Skilling v. United States, 56I U.S. 358, 405-I I (2010) (using the rules of lenity and constitutional avoidance to narrow the honest services fraud statute in an Enron-related prosecution, rather than striking it down for vagueness, as the dissent would have done).

107 John F. Manning, The Absurdity Doctrine, I I6 HARV. L. REV. 2387 , 239I-93 (2003).
} 
coherent theory, why a judge willing to fix a mistake viewed as a scrivener's error or an absurdity would not also fix a different kind of obvious statutory mistake or glitch.

Twenty-five judges told us that the idea of making vague or inscrutable statutes sensible was a necessary part of the judicial duty. One judge told us: "Our job is to try to make sense of what Congress intended. All you can go on there is purpose. But you can't say 'I give up' and use whatever makes sense to me. You have to do your best to figure out what Congress intended." Another said: "Yes, we try to make the statute work. If there is room I want the statute to fit and fit the surrounding legal typography like you do in the common law. That is a sensible starting point." Another told us that common sense was important to reaching a "just result. ... The equity of the statute is important to interpreting the statute." Another said: "That's the ballgame. The whole ballgame is to make common sense out of it."108

Several judges - interestingly, all noted textualists - couched this approach in the idea of "delegated" lawmaking power, and even suggested that judges should be more open about what exactly they are doing when they are filling gaps. This relates to the preoccupation we heard throughout the interviews with the federal courts" "legitimacy" in the interpretive endeavor, a word we heard more than we had expected. As one judge put it:

Yes, [judges should gap-fill,] with the qualification that judges have a duty of candor. If the judge is uncertain how a case should be decided, he should acknowledge his uncertainty in his opinion but explain that it is the judge's duty to decide cases even when uncertain as to the right decision.

\section{Another said:}

Congress has given interpretive power to the courts and in the process of interpreting what Congress has said you are also filling out what it didn't say. That's fair as long as you don't go too far. That's the inherent problem. The legitimacy is based on the federal statute but behind that is the inherent grant of authority in the statute to the judge.

Several judges of the older generation made the same point in the way reproduced below, which typifies a way of thinking that we did not see in the younger judges.

Consider, for example, the view of this older conservative judge, who takes a very broad view of his authority:

It's about legitimacy. I try to be faithful to that. I try to do what the Congress said. I don't want to adopt an interpretive enterprise for which I don't have authority. There is some inherent authority for when Congress leaves $A$ and $B$ out there to decide, you have given it to the court. We then have implied authority to go one way or the other. A lot of legislation is like that. ... When they are talking about congressional restraints on legislative action, reading statutes in ways that conform to those constraints is

108 Eight judges did not answer this question directly enough for us to categorize them. 
not a constraint on legislative power, it conforms to it. It's deferential to Congress. The enterprise for both is about legitimacy.

In contrast, the younger judges live in a post-Scalia interpretive world, one in which canons appear in books, catalogued and marking the basic boundaries of the field, and where themes of judicial restraint and the promise of formalism are emphasized. Some of the younger judges were quite surprised, when told after the interview of the different perspective we observed in the older judges. One, for instance said: "Inherent authority, delegation — that's really different from how we think about it today."

Another younger conservative judge explained that he sometimes relies on a common-sense approach but he prefers using canons as a way to answer the question when other tools run out. To his mind, and consistent with Justice Scalia's message, canons are more objective and allow for more consistency across decisions:

When it is obvious that Congress didn't contemplate the thing at all that's really hard. That is a good place to have canons and be consistent about it. Using canons consistently is a good thing. The instinct to do the interpretation that makes the most sense versus one that is canon driven is a hard tension. But I would probably pick the canons approach.

Yet almost all of the judges we interviewed told us that they do support the absurdities rule, with the caveat that the language has to be "truly absurd." Of the twenty-six judges who responded to our followup question about updating, eighteen said they would update, but not indiscriminately. Two focused on the age of the statute as giving greater justification for updating; two focused on indicia of delegation to courts (both noting that the Sherman Act is a particularly good example of a statute that judges should update because of its brief and general language $^{109}$ ); most of the others emphasized that updating is only appropriate if the updated reading can fit into the statutory text (even if Congress was not thinking about the issue when drafting); two more emphasized the fact that Congress generally does not do the hard updating itself and so courts have no choice but to do it.

\section{The Role of Eclecticism in the Judge-Congress Relationship - Echoes of an Intent-Based Approach}

The judges did not describe themselves as eclectic, but that is what emerged as the dominant judicial approach to statutory interpretation

\footnotetext{
109 Cf. Leegin Creative Leather Prods., Inc. v. PSKS, Inc., 55 I U.S. 877, 899 (2007) ("From the beginning the Court has treated the Sherman Act as a common-law statute. .. 'In antitrust, the federal courts ... act more as common-law courts than in other areas governed by federal statute."” (second omission in original) (quoting Nw. Airlines, Inc. v. Transp. Workers Union, 45I U.S. 77, 98 n.42 (I 98I))); William N. Eskridge, Jr., Public Values in Statutory Interpretation, I 37 U. PA. L. REV. I007, I052 (I989); Margaret H. Lemos, Interpretive Methodology and Delegations to Courts: Are "Common Law Statutes" Different?, in InTEllectual Property AND THE Common LaW 89, 9I-92 (Shyamkrishna Balganesh ed., 20I3).
} 
in our sample. The judges later confirmed these impressions when we asked them about it in the follow-up questions. The goal that this eclecticism aims to serve is a central question. The judges we spoke with indicated that the eclecticism is legitimating - we were surprised by how many judges were focused on their own legitimacy as much as they were - because it allows them to check their answers across all kinds of materials.

The eclecticism seems tied to the judges' sense, which we heard from many, that they are the second seat to Congress when it comes to statutes. Indeed, most of the judges we spoke with were much more focused on congressional intent and purpose than one would think from reading Supreme Court opinions alone. Despite the judges' disavowals of "purposivism" and their use of Justice Scalia's canons, virtually all of the judges we spoke to - including the text-centric ones - do appear focused on figuring out what Congress meant or what Congress would have done had it noticed the gap in the statute at issue. Consulting a lot of materials is their main way of doing this.

As one judge said:

When text doesn't really give you the answer why wouldn't you want to be eclectic? It seems a little odd to be dogmatic. The standard view is that the eclecticism is bad because it gives discretion to judges but that seems like a misplaced objection because on most of these questions I don't think the judge cares all that much about the answer, we just want to have a sense they are doing what the legislature wanted.

Although none of the judges described himself or herself as an "intentionalist," it appears to us that the judges' universal interest in linking interpretation to Congress — which is not the textualist or formalist mission as traditionally described - is why almost all do indeed care about purpose and legislative history, and why few care about things like dictionaries (which are not linked to Congress). This is also probably why none of our judges self-identified as a strict textualist.

\section{RELATIONSHIP TO THE SUPREME COURT, INCLUDING THEORIES OF PRECEDENT}

Most of the judges we interviewed did not hold the Supreme Court's approach to statutory interpretation in high regard. The wooden nature of the current Court's approach combined with inconsistencies across the Court's statutory interpretation opinions seemed to be contributing factors. Perhaps relatedly, and linked to several ongoing theoretical and doctrinal debates, most of the judges we interviewed did not view the Court's interpretive methodology as binding on them or as precedential. 
But the judges divided over why there is no "methodological stare decisis" in the federal courts. ${ }^{110}$

Methodological stare decisis, as one of us has detailed, is the treatment of statutory interpretation rules as precedents, just as courts treat analogous decisionmaking rules such as the parol evidence rule or burden-shifting regimes. ${ }^{111}$ Although the federal courts, including the Supreme Court, generally "give 'super strong' stare decisis effect to $s u b$ stantive statutory precedents"112 (interpretations about what a statute substantively means), the federal courts generally do not treat the methodology (the rules, presumptions, or other tools it applies) as precedential for the next case, even where the same statute is being construed. ${ }^{113}$ Federal judges often take the position that neither superior courts, nor Congress, can control their statutory interpretation methods. ${ }^{114}$

There is arguably no other area of law in which judges behave in this way - namely, in which Article III judges believe the decisionmaking rules for cases cannot be controlled by Congress or the Court. ${ }^{115}$ The lack of methodological stare decisis also dooms any formalist enterprise in statutory interpretation because it prevents a predictable approach from taking hold. We wondered how the judges we interviewed viewed this issue and also what, in their view, might justify treating statutory interpretation methodology as different from other decisionmaking rules.

I. Judges Who Believe the Supreme Court Can and Does Dictate Statutory Interpretation Rules. - Only six judges (four conservative, two liberal) gave an outright affirmative response to the question of whether the Supreme Court could dictate lower-court interpretive methodology. Representative responses were: "Yes the Supreme Court approach is binding. They tell us not just what we decide but how;" and

$110 \mathrm{Cf}$. Gluck, supra note 4 , at I823-24 (illustrating this phenomenon and noting the presence of methodological stare decisis in some state courts).

111 Gluck, supra note i9, at 1970-76, I978-80.

112 Id. at I $9 \mathrm{I} 7$.

113 Id. at I9I $7-18$.

114 Federal courts do not even consistently apply the Erie doctrine, Erie R.R. Co. v. Tompkins, 304 U.S. 64, 92 (I938), to state statutory interpretation cases. Where Erie commands that federal judges apply state law to state legal questions, federal judges often ignore state statutory interpretation rules when interpreting state statutes. See Gluck, supra note I9, at I924-58.

115 To be clear, the claim is not that overarching theories of interpretation should be given a firm legal status, but rather individual decision rules. In the constitutional context, for instance, we do not treat originalism as law but we do treat the tiers of scrutiny and the First Amendment balancing tests as precedential law. See Richard H. FALlon, Jr., IMPLEMENTING The Constitution 5 (200I) ("A distinctive feature of the Supreme Court's function involves the formulation of constitutional rules, formulas, and tests, sometimes consisting of multiple parts."); Mitchell N. Berman, Constitutional Decision Rules, go VA. L. REV. I, I67 (2004) (distinguishing "statements of judgeinterpreted constitutional meaning from rules directing how courts should adjudicate claimed violations of such meaning" and calling the latter "constitutional decision rules"). For a more detailed exposition of this argument, see Abbe R. Gluck, Justice Scalia's Unfinished Business in Statutory Interpretation: Where Textualism's Formalism Gave Up, 92 NOTRE DAME L. REV. 2053 (20I7). 
"[w]e can disagree on the outcome but if the Court tells us we have to use a canon, we have to." One judge not included in this group put it this way: "It is sort of dicta but it is also reasoning. . . . We should follow it." Three other judges not included in the aforementioned group told us that they do not view the interpretive methodology as binding, but use it "because it is persuasive to your colleagues and whoever is reviewing." Two others made clear that the Supreme Court's approach affects how they decide cases, but not because they feel bound by theories of precedent:

That is not to say I don't use their methods sometimes, but I don't think about it as a question of following them. With preemption and retroactivity, those are their canons and I do follow them. I don't think I would cite them for expressio or ejusdem but God help me a law clerk might throw a cite in. I am much more interested in a court holding than how they got there.

2. Judges Who Believe the Supreme Court Cannot Dictate Statutory Interpretation Rules. - Fifteen of the judges did not think that the Supreme Court has the power to bind lower-judge interpretive methodology, even if it wanted to. Some of these judges took this position because they view the interpretive rules as common sense, "tools," or "useful guides," but not as legal principles that could bind. The rest of them were in the camp that poses the most challenging jurisprudential question about statutory interpretation - namely, why statutory interpretation seems so much more inherently personal to the individual Article III judge than do analogous decisionmaking rules ${ }^{116}$ in other contexts in which the Supreme Court unquestionably dictates the controlling rule.

Even among these judges, however, there were exceptions for certain canons. One judge said the exceptional doctrines - the ones that are indeed binding — are the ones based on "constitutional principles." Another judge singled out a few canons - namely, lenity, preemption, and avoidance — as "rule[s] of law, not . . . interpretive principle[s]" to which he would defer. Another said: "In practice, I would definitely pay very close attention to how they decide a case, but I don't really know that the way the system is structured and Article III that it would bind me as a judge." Others were more definitive: "I don't think those [imposing interpretive rules] are in their power." Even some who argued that "it's not part of the holding," admitted they would be "more skittish the next time" to use an interpretive tool or rule disavowed by the Supreme Court.

In contrast, when asked in the very next question about Cheoron deference - the interpretive rule that courts must defer to reasonable agency interpretations of ambiguous statutes - every interviewed judge told us this rule is binding even if they disagreed with it. Not a single judge made the connection between the previous question — about the

\footnotetext{
116 Including, but not limited to, the parol evidence rules, the burden-shifting rules, and the tiers of scrutiny.
} 
potential for other methodological rules to be binding - and what was, to them, the indisputable precedential weight of Chevron.

3. Judges Who Believe the Supreme Court Could, but Has Not Yet, Dictated Interpretive Rules Because the Court Is Too Inconsistent. Eleven said the Supreme Court's methodological approach is not precedential because the Court itself has not decided on a consistent approach, and not because the Court does not have the power to impose methodology as rules of law. ${ }^{117}$ They made comments on the order of: "I don't feel particularly bound by the Supreme Court because they aren't consistent" and "[t]he Supreme Court has such a varied approach to all this, I'm not sure there is a consistent message being given to us."

Typical of this group was the comment that the Supreme Court could establish rules of interpretation, but has not yet spoken with sufficient clarity to do so. One put it this way:

Does their methodology bind us? To the same extent that it binds them. If they say "our statutory methodology is we allow agencies to resolve ambiguity using things like legislative history and policy," then that Cherron rule binds us because they say, "that's our interpretive rule." On the questions that divide textualists ... and pragmatists, you have textualists and pragmatists on the Supreme Court and neither of them has been squelched by the other, so why would judges on the courts of appeals feel squelched either way?

Another said:

On the surface, the tools we use look the same, but [the Court isn't] bound by anything. They are so much more free-form than we on the Court of Appeals are allowed to be. So it goes the other way. They present to be bound, and really are hardly bound at all. We are very much bound by what the Supreme Court tells us to do. My conservative colleagues try to curry favor with Justice Scalia by not looking at legislative history, but I don't feel bound by that even when he has a majority of the Court. We'd have to distinguish between different types of interpretive tools. I take the word "presumption" seriously. I do feel bound by the presumptions against preemption. I do take those seriously and feel bound by them. But not by the way the Court says we should go about interpreting congressional meaning.

$$
* \quad * \quad *
$$

These answers lend support to our previous intuitions - that despite the prevalence of statutory cases on the federal docket, most federal judges have given very little thought to why they apply the interpretive rules that they do and the legal status of those rules. We do not intend to single out our interviewees for special criticism: the Supreme Court itself does not appear to have given serious thought to these questions, and that ambivalence about the legal status of interpretive rules, as

117 Five judges did not directly answer the question. 
many of the judges we spoke to noted, has trickled down. However, it remains a jurisprudential puzzle. We cannot think of another area of law in which there is so much uncertainty as to whether the rules to be applied could be dictated either by the Supreme Court or by Congress, and no concrete theory to govern that conclusion.

4. Judges Do Not Want More Guidance from the Supreme Court. At the same time, no one wanted more guidance from the Supreme Court. Most of the judges expressed more confidence in their own court's abilities than in those of the Supreme Court. They made comments like: "I actually think my court does a pretty good job. We work really hard. . . . I'm very happy with the way things are."; "I don't want guidance from the Supreme Court. I do not think they are intellectually particularly sophisticated. I think the lower federal courts are pretty good. I would much rather argue with some other court of appeals judges like Frank Easterbrook and the late Richard Arnold than the Supreme Court."; "I don't know what I would get from the Supreme Court. I have no confidence in them."; and "I am very comfortable with where my court is."

Others wanted even less guidance from the Supreme Court. One said: "I don't think it would be hugely helpful to have lots of instructions from them on how to interpret statutes, especially because I don't think they could give the instructions in ways that could be clear." Another recognized the risk of settling on a single interpretive methodology: one can never be sure which rules the Supreme Court will pick. That judge said, "As of right now I am more comfortable getting less guidance from the Supreme Court because I don't know what it would be." We suspect this fear drives some of the other judges' resistance to methodological stare decisis, too.

5. Guidance from Congress? - A few judges wanted "more guidelines from Congress." Others said all they would ask from Congress is to "just write better statutes! That's the problem. They are so poorly drafted and we as lower courts are stuck trying to figure out what Congress intended." Another said: "If Congress could pay more attention to remedies and retroactivity and stuff like that when they are drafting, it would be a lot better. It would be better if Congress would think through the application of that statute, who gets to sue, what do they get to sue for - that would be helpful." Chief Judge Katzmann has recommended something in this vein, namely, a "checklist" for congressional drafters so as to reduce "oversights" and make "legislative intent" clearer. $^{118}$

\footnotetext{
118 KATZMANN, supra note 48, at 93-94. A checklist might include, for example, the issues of: "attorneys' fees, private rights of action, preemption, statutes of limitations, effective dates, and exhaustion of administrative remedies." Id. at 93; see also Kavanaugh, supra note 48, at 2 I33 ("agree[ing] fully" with the checklist approach that Chief Judge Katzmann describes).
} 


\section{DEFERENCE TO AgENCIES AND CHEVRON SKEPTICISM}

Although every judge we interviewed told us that he or she was bound by Chevron - and all but one of the judges did apply that rule in opinions ${ }^{119}$ - most of the judges we interviewed do not favor the Chevron rule. Here is where we see a "D.C. Circuit effect" in our study. All but one of the D.C. Circuit judges we interviewed - who were of different generations and political parties - were admirers of Chevron deference, whereas most other judges from the other courts of appeals were decidedly anti-Chevron.

Some said something similar to this judge's comment: "I apply it because I don't see any way out of it." One complained that "agencies are very muscular nowadays." Another said: "[T]he problem is that the administrative agencies are not independent. Sometimes there is a good reason to defer but it happens more and more and more. . . . I don't like it because I don't like administrative agencies and I don't like deference to dependents." Some expressed skepticism about Chevron's fiction of delegation, arguing that: "for actual delegations, Chevron is acceptable, but that a lot of times judges are talking about delegation, but nothing has really been delegated to the agency. Then I'm skeptical about using the Chevron approach."

The judges expressing skepticism regarding Chevron divide equally among liberals and conservatives. Consider, for instance, a comment from one of each perspective, of the same generation and court of appeals: "I follow Cheoron, Skidmore, and Mead, but if I had my oats, I would get rid of most of the agencies altogether because they do a terrible job, and it is very bad lawyering"; and:

[Since] Cherron is the law, I am obliged to use it. I think it is a terrible rule.

Chevron isn't just a throw-away canon, it is a basic law. It's terrible. We

should use agency expertise when [agencies] are assessing facts. That's what they are good at. They don't know more about the meaning of statutes than

I do. It's my job to interpret statutes.

Here are two more judges, again liberal and conservative, from the same generation (but a different generation from the above pair) and on the same court of appeals: "I would prefer a little less deference to the agency. It's so unseemly: You don't want an agency changing its view with every President;" and "from a personal standpoint, I would prefer that I had more authority, but I do feel that we have to apply the deference that the Supreme Court has set out. There's a lot of agency self-interest involved - the natural agency tendency toward selfaggrandizement." Only four non-D.C. Circuit judges said they were satisfied with the balance Cherron strikes, specifically pointing to how

119 That judge was a recent appointee who had not had a case requiring a citation of Chevron yet, but who had signed onto numerous opinions citing the case. 
it relieves judges of having to do extra work or go too deeply beyond their expertise.

Because all of the judges told us that they felt bound by Chevron, we were not surprised to see little evidence of their distaste for the doctrine in opinions. Nevertheless, in our random sampling of their opinions, we found that three judges who were particularly emphatic about their dislike of Chevron did defer less than fifty percent of the time (a lower rate of deference than the others) and expressed Chevron skepticism in opinions. Another judge who told us he obeyed the doctrine but had come to question it wrote opinions that reflect that as well.

We note that Chevron has come under more academic and judicial attack recently, in large part linked to the stated opposition to the doctrine by newly confirmed Supreme Court Justice Gorsuch. Even though the most vocal public critics of the rule tend to be associated with legal conservatism, ${ }^{120}$ our survey indicates that judicial discomfort with Chevron may be more common, and politically balanced, than one might think. To that end, it is relevant that thirty-five out of the forty-two judges we interviewed were interviewed before Justice Gorsuch's nomination. It is possible that some judges would be less frank with us today about their Chevron skepticism, given that the nomination politicized the Cheoron debate to some extent.

The D.C. Circuit judges we spoke with are different. They accept Chevron as part of the basic wiring of how that court decides cases and generally are comfortable with it. As one said:

I've gotten to the point where I don't much care; I can understand both sides of it. It does establish a framework that keeps us somewhat confined. ... I'm just not sure that without the framework judges would do a better job than agencies. What I've come to believe is that as long as we are within a clear framework, it confines us in good ways. I think Chevron is relatively clear .... In our Circuit we have gotten into a routine in applying it.

Although one D.C. Circuit judge told us that "generally, I do think Chevron is a good rule," and another that "because the issues of statutory

120 See, e.g., Gutierrez-Brizuela v. Lynch, 834 F.3d I 42, I I 49-58 (Ioth Cir. 20I6) (Gorsuch, J., concurring) (suggesting that Chevron is unconstitutional); Jonathan H. Adler, Restoring Chevron's Domain, 8I MO. L. REV. 983, 983 (20I6) (noting "Chevron's domain is under siege" (footnote omitted)). Justice Thomas has written a series of opinions criticizing Chevron deference and other forms of judicial deference to agency interpretations. See, e.g., Michigan v. EPA, I35 S. Ct. 2699, 27I2-I4 (2015) (Thomas, J., concurring); Tex. Dep't of Hous. \& Cmty. Affairs v. Inclusive Cmtys. Project, Inc., I35 S. Ct. 2507, 2529 (2015) (Thomas, J., dissenting); Perez v. Mortg. Bankers Ass'n, I35 S. Ct. I I99, I2 I3-25 (2015) (Thomas, J., concurring in the judgment); $c f$. Wellness Int'l Network, Ltd. v. Sharif, I35 S. Ct. I932, I96 I (2015) (Thomas, J., dissenting) (describing the system of separated powers as not permitting the exercise of another branch's delegated power); Dep't of Transp. v. Ass'n of Am. R.Rs., I35 S. Ct. I225, I240-45 (2015) (Thomas, J., concurring in the judgment) (same). Some liberals have attacked Chevron too. See, e.g., Jack M. Beermann, End the Failed Chevron Experiment Now: How Chevron Has Failed and Why It Can and Should Be Ovemuled, 42 CONN. L. REV. 779 (2010). 
interpretation do involve policy consequences, and because the agency is supposed to be knowledgeable about that, and because the agency is susceptible to political influence and policy, it makes sense," two expressed some new reservations about Chevron. As one put it: "I've become somewhat more doubtful as time has moved on, I guess because of fear of usurpation of Congress."

\section{MORE ON THE JUDGES' INDIVIDUAL APPROACHES}

For our final series of questions, we asked the judges how they developed their own interpretive approaches; how they would characterize their own interpretive approaches; how they use (or do not use) lawyers and law clerks in statutory cases; and an open-ended final question designed to elicit anything we had left out. The most salient finding is the one we already have noted: namely, that almost no one was willing to identify him or herself as either an unqualified textualist or purposivist. In addition, all of the judges seemed to have developed their approaches "on the job," without self-conscious election. Previously held jobs, unsurprisingly, had an important influence.

\section{A. Judicial Approaches Adopted Incrementally, Case by Case}

One surprising response we received from many judges is that they "never thought about" how they developed their approach. Most told us it was "experiential." And many emphasized that they don't have "a theory."

Those who had previously worked in government stood out from the others, in terms of the formative nature of that work for many judges. Many told us that, as government lawyers, they worked frequently with statutes, and that work influenced their later perspectives as jurists. One put it this way: "My coming at it continuously for now twenty-eight years, it's experience." Another said that our question — how judges came to develop their own interpretive approaches - "makes it sound more deliberate and informed than it could possibly be. I'm just a common law judge, and I make sense of it." Several mentioned that they read books written by experienced judges, including Posner and Chief Judge Katzmann. A few were influenced by the judges they clerked for and the kinds of fights in which their mentor-judges engaged with judges at the opposite extreme. As one said: "Trial and error. I worked for two very different [judges] before. . . I read the literature both of you guys write. My fear of getting it wrong is a big driver for me."

We were somewhat surprised that no judges mentioned specific subject matters as driving forces behind their choice of interpretive approach, apart from the many judges who singled out the rule of lenity as important in criminal cases. Instead, all seemed to accept our general premise that judges have a basic approach that applies to all kinds of 
cases. We cannot offer firm conclusions on this point, however, because we did not ask them about subject-specific approaches.

\section{B. Role of Lawyers and Law Clerks}

The judges also divided down the middle regarding the helpfulness of law clerks and lawyers in statutory interpretation cases. Several judges told us that law clerks who have "had a course in law school exclusively dealing with statutory interpretation ... bring more to the table. It's a very sharp distinction." Another judge told us that clerks are helpful because they "come up with possible ways of doing things in contrast to my original reaction to the case." (On the other hand, some of the judges seemed to have none of these clerks! They complained that their clerks do not come prepared on the rules of statutory interpretation.) Most of the judges acknowledged limits to "what the law clerks can do," and explained that they usually have to be taught what to look for. One judge pointed out what may be a generational effect of the way legislation is currently taught in law schools: "Coming out of law school, the [law clerks] tend to know the Scalia and Garner approach pretty well. They may be more textualist than I am. They often give me five to eight pages of statutory text rather than really getting into the cases. I would love to get my law clerks past that."

With respect to lawyers, most of the judges recognized the varying quality of lawyers' briefs and told us they freely discarded the briefs of counsel of poor quality. Many judges mentioned that lawyers' efforts at zealous advocacy in statutory interpretation cases often backfire and make them less helpful to the courts, with each side being overly rigid, or both sides insisting their reading of the text is the only clear reading. Here, too, we saw a D.C. Circuit effect. Our D.C. Circuit judges repeatedly mentioned the high quality of the government counsel often before their court as a benefit. They emphasized that government lawyers and their briefs can be very helpful. The following comment is a good example:

By and large government counsel are quite good, with few exceptions. Some are extraordinary. We are likely to get a lot of help in government briefs. The other side's briefs vary a lot more. Some appointed lawyers, like lawyers appointed under the Criminal Justice Act, are quite unhelpful in cases involving statutory interpretation. But big law firms are really terrific. I generally get a lot of help from the briefs on statutory interpretation. It's help in the sense they both explore the statute and their possible interpretations pretty thoroughly. When they are unmatched, I myself and clerks have to figure out the other side.

Most of the judges recognized that "lawyers are all over the board" and that many "aren't really as helpful as they should be." One judge pointed out that:

[Lawyers] are obsessed with plain meaning. You get both parties each arguing his interpretation is plain meaning. How can it be you have the same 
phrase that has opposite "plain, literal meaning" — not as a matter of history or purpose, but just as a matter of literal meaning? It's a masquerade, but they harp on that.

Another similarly told us the lawyers are often not helpful because they are too "scripted."

\section{Is Statutory Interpretation Different from Other Modes of Judicial Decisionmaking?}

Finally, about one third of the judges we interviewed commented on how statutory interpretation cases differ from other kinds of cases. One judge emphasized the fact that most statutory cases, unlike constitutional cases, involve relatively recently drafted text: "In interpreting the Constitution, you often have the lay of the land and something that was written two centuries ago, and you have to be well aware of changes in language and context. But most of the statutes that we interpret are less than roo years old."

Most of the judges, however, focused on the fact that, in statutory interpretation, the judge has to be "more constrained." Several judges thought that statutory interpretation was more "objective" than constitutional interpretation. As one put it:

I think constitutional questions and answers are more malleable based on the nature of the document and the history of inquiry. It's much looser. I don't feel that way about statutory interpretation. I feel there is a railroad track and I take the train.

One judge told us he was more comfortable deciding statutory cases because Congress can always fix an error in interpretation. Another judge told us, in contrast, that he is especially cautious in statutory cases because the courts rarely overturn statutory interpretation holdings themselves (contrasted with constitutional law holdings, which courts more readily revise).

A different way of articulating the difference came from this judge:

Constitutional and statutory interpretation on the one side, we're supposed to be carrying out someone else's charge. The common law is very different. In the common law world, where there's a statutory delegation like the Sherman Act or a constitutional delegation like the Supreme Court's original jurisdiction, then we are the primary anchor. You have a different approach when you are carrying out other people's commands than when you are trying to figure out the best answer.

\section{CONCLUSION}

Our study of federal appellate judges reveals a host of topics about statutory interpretation that pose far more interesting questions than do the old debates about text versus purpose. The study also adds more context to our understanding of interpretation than what emerges from 
the Supreme Court's cases and most of the academic literature about the field.

The last three decades' march toward a more formalist approach to interpretation seems more qualified in the lower courts, even though it indisputably has shaped the thinking of many judges. We saw in our interviews the influence of that progression in the younger judges' internalization of many of the canons of construction. But most of the judges whom we interviewed still emphatically defended their willingness to consult all available materials as the most legitimate way, in their view, to reach the right result and one consistent with Congress's intent.

We also saw the influence of formalist thinking in how our judges think about opinion writing and about public perceptions of their own legitimacy. Most of the judges we interviewed implied that, whatever their own views, their sense of what the public may perceive as the appropriate decisionmaking approach may be different. Most of the judges indicated that they are not fully explicit, in their opinions, about what seems to be a common law-type decisionmaking approach. Instead, they seem to see the public legitimacy of the endeavor as requiring more formalist reasoning - and more doctrinal use of the canons than the decisionmaking process itself. The question of how much work the canons are really doing and how much is mere "show" (or cover for the common law tools they wish to deploy) is difficult to resolve. It also illuminates a possible tension between the internal and external sense of judicial role that judges seem to experience in statutory cases.

That tension may also be behind some of the resistance that the judges we interviewed feel to using methodological precedent in statutory interpretation. An approach that is closer to a common law and/or pragmatic approach may be less amenable to doctrinalization by methodological precedent than an approach that is truly guided by the canons, exclusionary rules for certain materials, or other interpretive approaches.

We also wonder whether these federal court of appeals judges really are more pluralistic in their approach than the Supreme Court Justices, or whether we simply were able to have more candid conversations with them. But maybe the nature of the Court's bench - the same nine Justices sitting together on every case - requires a more formalist approach in order to garner majorities given the particular methodological outlook of those Justices. In the last few years of Justice Scalia's life, for instance, it was common to see opinions that placed all discussion of legislative history in a final, separate part, so that Justice Scalia could join the entire opinion except that part. That kind of methodological insistence and the lack of rotating panels may make the Court's interpretive approach more regimented in more cases. Time will tell how the death of Justice Scalia affects this.

These observations do not explain all of our findings. For instance, why do judges, even with the common law and pragmatic sensibilities 
we saw in many of them, feel comfortable amending statutes to eliminate absurdities but not other mistakes? Why is it that the D.C. Circuit judges - the judges on the court with the most experience with administrative law - appear to be much more strongly in favor of the Chevron deference principle than others? How do judges really understand their role and what legitimates it? These are some of the most important and intriguing questions for the future of the field. Our study reveals the benefits of approaching them from a vantage point that extends beyond the Supreme Court. 


\section{APPENDIX: REPRESENTATIVE INTERVIEWS}

We reproduce here six interviews that characterize the different types of judges we interviewed. We have redacted where necessary to preserve confidentiality.

We asked each judge the following nineteen questions, plus three additional follow-up questions. ${ }^{121}$ We do not reprint the questions for each judicial response reproduced below, but each response tracks this same questionnaire. ${ }^{122}$ In some cases, questions were skipped, typically because they were answered in the context of other questions. ${ }^{123}$

QI. When you get a case involving statutory interpretation, where do you begin in determining how the case should be decided?

Q2. What do you do if the statutory provision that you are asked to interpret is either ambiguous or vague? What role does plain meaning play in your interpretation of statutes?

Q3. Do you find dictionaries helpful in assigning meaning to a vague or ambiguous statutory provision?

$Q_{4}$. Our survey uses the word "canons" in a broad sense - although we understand that not everyone does that. Some of the canons are linguistic in the sense of concerning the relations between words in the statutory provision to be interpreted. An example is the canon that a word in different parts of the same statute should mean the same thing. Some of the canons concern relations between the statutory words and a policy or norm. Examples are the rule of lenity in criminal cases, the presumption against inferring that a federal statute preempts a state statute, the canon of constitutional avoidance, and the presumption favoring American Indian tribes in interpreting a statute relating to a tribe. Are there particular canons of statutory construction (in either of the two senses in which we're using the term) that you find either helpful or not helpful in statutory interpretation?

Q4A. Do you cite canons in judicial opinions? If so, why?

Q5. Do you ever rely on legislative history to help you determine the meaning of a statute? If so, what types of legislative history do you find most and least helpful?

Q6. Further, on the topic of Congress, do you think it important or at least helpful that judges understand the details of the legislative process - for example the role of congressional staff in drafting, relative to the role of the legislators themselves, or how statutes are sometimes

\footnotetext{
121 As noted, nineteen of the first thirty-five judges we interviewed responded to the follow-up questions. The remaining seven were asked the questions as part of their initial interview.

122 In some cases, judges anticipated the next question and answered a later-coming question together with an earlier one. For those judges, we skipped the later question. We occasionally skipped other questions in the interest of time for extremely long interviews.

123 Questions 4 and $4 \mathrm{~A}$ and I3 and I4, for instance, were often answered together. Question I8 is not listed with a response when one judge told us she or he had nothing else to add that we had not asked about.
} 
drafted by multiple committees, each taking responsibility for just one part of the statute and perhaps not even communicating with the other committees? Could or should such insights into the legislative process influence statutory interpretation — for example might or should a judge's awareness of multiple-committee drafting undermine the canon of construction noted earlier that the same statutory term or language has the same meaning throughout the entire statute?

Q7. Do you think it a proper judicial task to try to interpret a statute in a way that will make it internally consistent even if there is no indication that Congress focused on internal consistency?

Q8. Relatedly, do you ever try to determine the purpose behind the statute and interpret the statute so it will be most effective in achieving that purpose?

Q9. Do you think it a proper aim of judicial interpretation of statutes to try to make a vague or ambiguous statute as sensible as possible, at least with reference to issues of interpretation that Congress may not have foreseen arising?

Qro. Do you agree or disagree that the plain meaning of a particular statutory provision can be disregarded if adopting that meaning as the statutory meaning would yield absurd results or deflect the obvious legislative aim?

QII. How did you develop your own approach to statutory interpretation?

QI2. The Supreme Court decides many statutory cases, often invoking canons of statutory construction, dictionary definitions, legislative history, and other sources of interpretive guidance. Do you feel bound by whatever methods the Court uses in interpreting statutes? That is, are interpretive rules laid down by the Court holdings that operate as precedents in future cases involving statutory interpretation?

Qr3. Thus far our implicit focus has been on statutory issues that arise in appeals from federal district courts. But often such issues arise from decisions by federal administrative agencies, decisions that, like those of district courts, are appealable to a federal court of appeals. Do you treat such appeals differently from how you treat appeals from district courts?

QI4. How much weight do you give to doctrines, such as Chevron, Mead, and Skidmore, that counsel strong deference to the interpretation of vague or ambiguous statutory provisions by the agencies charged with administering them? Do you think those doctrines strike the right balance between judicial and administrative interpretation of statutes?

Q I5. Is there a single word that would describe your approach to statutory interpretation, such as textualist, contextualist, purposivist, or pragmatist, or anything else?

QI6. What role do the lawyers and your law clerks play in how you analyze a statutory interpretation case and explain your decision in your opinion? 
QI7. Do you think the way that the federal courts are interpreting statutes is working well? Would you want more guidance on statutory interpretation from Congress or the Supreme Court?

QI8. Is there anything I haven't asked you that you consider important to how you interpret statutes, or that differentiates in your mind statutory interpretation from common law and constitutional decisionmaking?

FOLLOW-UP \# I. The dominant theme that emerged from the first thirty-five interviews that we conducted is that federal appellate judges are quite eclectic in their approach to statutory interpretation: almost everyone we spoke with was willing to consider text, canons, legislative history, practical considerations, etc., to some degree. We would be very interested to hear your reaction to this. Specifically, why do you think federal appellate judges are so eclectic in their approach? Do you think this eclecticism is laudable or problematic, and why?

FOLLOW-UP \#2. Although we asked about the judge's role when a case implicates a statutory question that Congress did not foresee when drafting, we did not ask specifically about the judge's role in updating statutory language to harmonize an older statute with the modern legal context. Is that something you feel is part of the judicial function in statutory cases?

FOLLOW-UP \#3. Although we discussed at length the various tools judges use to decide cases, we did not discuss how you actually come to your decision, or at what point in reviewing the materials - whether bench memos, briefs, or other materials - the decision generally becomes solidified in your mind. Recognizing this may be hard to articulate, is it possible for you to describe to us how that happens for you?

\section{A. The Most Text-Oriented Type of Judge}

QI. I [start by] ask[ing] what does the statute say.

Q2. If I think the provision is ambiguous, I do a couple of things. First of all, I look at the cases and see if someone else has already decided this. We have quite a lot of law in this circuit. We may not only have said something about a statute, but maybe did it - definitively interpreted it - a few times. Then I look at structure. At some point, I'll start looking at tools like legislative history. I'll look at almost anything in that - committee reports, floor statements. I'm skeptical of it, but I most certainly will look at it.

If the meaning were absolutely plain, that would be the end of it for me. In the original version of CAFA enacted in 2005 , there was a provision that the time for filing was not less than seven days after the district court issued its order. It turned out that it was seven days or more. It looked like a seven-day waiting period. To me, it did look like it was a mistake ... [but] [i]t was mathematically ascertainable and grammatically written. This was a problem Congress had to fix .... 
Q3. [Dictionaries are] [n]ot terribly helpful. If I have an ambiguous term, a phrase I'm not familiar with, I look at dictionaries to make sure I'm in the ballpark. I've used dictionaries when I was looking at a constitutional provision or a statute from the Founding era.

$\mathrm{Q}_{4} \& \mathrm{Q}_{4} \mathrm{~A}$. I know for every canon there seems to be an opposite and equal canon - dueling canons - but those kinds of rules are I think useful. I don't think any single one can be definitive because each has an exception.

I can't think of an instance where I've cited a canon but I'm sure I have. The linguistic canons are general rules of how we are going to treat some kind of language - like ejusdem. That rule codifies common sense. That rule at least tells me something about human nature.

I haven't thought about the canons globally or divided them into two camps of language and policy. For example, the rule of lenity. Most lenity arguments aren't based on ambiguity, and so there are very few cases where the rule of lenity has an effect. It's just a step short of holding something void for vagueness.

Q5. [On use of legislative history, already answered, says yes.]

Q6. I think understanding Congress helps. It contributes to my skepticism of how legislative history is created. Anyone who has visited the gallery of the House or Senate and seen someone lecturing to an empty chamber will appraise floor statements differently. In the I99I Bush Administration, there was an amendment to the Civil Rights Act that oddly was uncontested. The sides agreed there would be no legislative history. That was a really interesting second-order awareness of the issue of legislative history. It's unusual to be able to get down into the weeds of legislative process. I have an example of a recent case where the parties were going through iterations of congressional drafts and what language was taken from what draft. I'm willing to look at it. We do some of that in con law: we look at the original draft of the Bill of Rights.

Q7. If I thought there was inconsistency in the statute of course I'd have to figure out how to harmonize it. But if I was aware of a legislative compromise or White House negotiation and there was some kind of sidebar agreement - if you are aware of such a deal, it's hard to ignore it. It's hard to use it as a rule of interpretation but I'd be affected by it. But as a judge, I'm not sure I can go to the New York Times or the Washington Post and say here's the backstory of how the legislation was adopted. I'm not sure I can use the New York Times as an interpretive construct for understanding a statute.

Q8. [Not asked.]

Q9. [On pragmatism:] If there are multiple plausible interpretations, I have no legislative history to look at, no clue from structure, then yes, I'll give it the most commonsense interpretation I can.

QIo. You have to be very careful about what you think is absurd. A majority of our court thought [redacted case name] was absurd, but 
my response was, how could that be? It is perfectly understandable even if it wasn't intended, so our job is to let Congress change it. [Regarding the famous "no vehicles in the park" hypothetical:] It would be so silly. The political consequences to the DA would be significant. I'd let those consequences flow, as a matter of discipline. Let the DA suffer the consequences of his silly interpretation. I think part of the consequence of Marbury is that, over time, Congress has stopped reading the Constitution. It presses the limits of its power, and lets the Court be the backstop. I don't think that's salutary interpretation.

QI I. [On developing the judge's approach:] As a lawyer at DOJ, I briefed a large number of cases with statutory questions. As an appellate lawyer in the Justice Department, I didn't handle anything at trial and I had to educate myself about statutes I'd never heard of. So every time I started a case, I had to pull the whole statute to really understand it in context. That was extremely helpful.

QI2. [On precedential weight of interpretive rules:] The Supreme Court has such a varied approach to all this, I'm not sure there is a consistent message being given to us. I don't go as far as Justice Scalia does on legislative history. I'm willing to look at it. I don't think I can go that far. I think it's very hard to draw rules from the Supreme Court because there are always exceptions, like dueling canons.

QI3 \& QI4. We have to give some deference when the agency has given a plausible interpretation. They are a coequal interpreter, they have a broader perspective on the whole scheme, so I'm on board with Chevron. However, the agency is not entitled to deference if what it is doing is expanding its own authority.

QI5. [On one word to describe interpretive approach:] Textualist. I would add being a contextualist. I'd want to be sure we'd use the rest of the act as a lexigraphical tool to interpret the whole thing.

Qi6. Lawyers are all over the board. It depends on how sophisticated the particular lawyers in the case are. A lot of my clerks may not have had Washington experience or understand the legislative process. Sometimes I have to train a clerk what to look for. We are doing a better job teaching legislation than when I was in law school. I'm not sure it was recognized as a class, but I've found a lot of law schools are offering classes in legislation. I think we are doing a better job of that. I'm not sure how much clerks know about the legislative process. They treat all legislative history alike, for example.

QI7. [Not asked.]

QI8. There is a difference between common law methodology, statutes, and the Constitution. I regard the Constitution as a form of civil law - our written Constitution was an American innovation, different from England. And therefore I read the Constitution narrowly, as if it were a statute. But I do think there is a difference between statutory law and common law methods. Statutes are easily amended whereas in 
the common law methodology we have to overrule ourselves. I'm careful about statutory interpretation because the Court rarely overrules itself on statutory construction. The Court overturns itself a lot more on constitutional law than statutory law.

\section{B. Older-Generation Judge/Legal Process Institutionalist}

Q I. I want first to see the whole statute not just the section given to me in the briefing. I look at the precise language. I look at whether this is a question we have interpreted before and whether the uncertainty in the statute is some type of oversight of draftsmanship or there really was a decision between $A$ and $B$. I'm not really interested in what Congress did or if they kicked the can down to us. If they kicked the can I am still operating within the overarching guidelines of the statute itself.

Q2. Plain meaning is a matter of linguistic inference. I use common sense. If a word is used in a way that's particular to the statute I take an inference from the language.

Q3. I don't get a lot of confidence from the dictionaries. Maybe for a technical term.

$\mathrm{Q}_{4} \& \mathrm{Q}_{4} \mathrm{~A}$. I think [canons are useful] in the broad sense. There are guidelines that are helpful, reminders of what I think intuitively is the answer anyway. Some of the canons are resting on a normative choice of course but others are basic principles like constitutional avoidance. ... The clerks add them as signposts. The clerks come back with detail. I find the writing among clerks to have a wide range of quality. Working with facts is the hardest. Good trial lawyers can find narratives out of the chaos of facts.

Q5. Sometimes you can get a sense of the case [from legislative history]. Sometimes I tack it on at the end.... I follow the law and then check to make sure it is right. The notion you just ignore it does not make a lot of sense. The question is what kind of controlling weight to give to it. You have all sorts of reports, comments, etc., but it sometimes informs you of issues they considered or wanted. Not for getting down to the issue of he said this or he said that, but a question about what the fight was about. What are the stakes? Legislative history helps me to define when the fight is over.

Q6. It would serve a judge well to have working knowledge of the realities of the legislative process. Scalia had a keen awareness of that, a healthy skepticism that informed his textualism. I have never seen judges being trained on the realities of the legislative process. I would love to see things on this. They sign onto the words, so it has to be about the words whatever the process is, but the words can never be the ending point because what appears to be pretty straightforward becomes unraveled in context.

Q7. [Not asked.] 
Q8. This is common law, interstitial work. It is filling out a statute to make sense of its natural purpose or to work more efficiently. It goes back to the question of whether it was an oversight or not.

Q9 \& QIo. Congress has given interpretive power to the courts and in the process of interpreting what Congress has said you are also filling out what it didn't say. That's fair as long as you don't go too far. That's the inherent problem. The legitimacy is based on the federal statute, but behind that is the inherent grant of authority in the statute to the judge. You are interpreting and giving meaning to those words.... Everyone reads differently. There is inherent fluidity of language. The canons are very helpful in reminding people to think about certain things and reminding judges that their job is not to make new law. A lot of states have interpretive statutes but we never consult them. . . It is very helpful when it comes to legitimacy to have a statute and make Congress be clear.

QI I. It's about legitimacy. I try to be faithful to that. I try to do what the Congress said. I don't want to adopt an interpretive enterprise for which I don't have authority. There is some inherent authority for when Congress leaves $\mathrm{A}$ and $\mathrm{B}$ out there, you give it to the court. We then have implied authority to go one way or the other. A lot of legislation is like that. Another thing Congress does is it enacts agencies as a backdrop for judicial interpretation and opinions that are already there. There is legitimacy in looking to that backdrop. When they are talking about congressional restraints on legislative action, reading statutes in ways that conform to those constraints is not a constraint on legislative power, it conforms with it. It's deferential to Congress. The enterprise for both is about legitimacy. Textualists have certain techniques - canons, accountability, and agency interpretation, all these things are really trying to move in the direction of a good state of legitimacy.

QI2. [Question not answered. View that Cherron does not appear in Constitution was response.]

Qг3 \& Q i4. Congress delegates to administrative agencies. Okay. It's a separate question on what grounds Congress has exercised that power. I understand there is Article I, Article II, and Article III, but then you've got this administrative apparatus. Where is that in the Constitution? I don't know the answer. It is intriguing. But we don't see any real challenges to it. [Even if there were no Cheoron] there still must be some deference. The deference would still be the same. I don't think the deference from the lower federal courts should be greater to agencies under Chevron. You give deference because the issues are complex.

QI5. I am a textualist with a very strong streak of pragmatism. I have become more pragmatic over the years. I find myself asking: is there really a problem? 
Qi6. Some cases I know the answer to. Others I just don't know the answer. [If] after reading the briefs and the record I am still uncertain I sit down and I work by long hand. Lawyers often don't understand the issues - they are often mechanical in their approach.

QI7. [Not asked.]

FOLLOW-UP \#I. That eclectic emerged as an overarching description of the responses of thirty-five appellate judges does not surprise. One can see text, canon, legislative history, etc., as tools or aids to a judge's decision as distinct from principles or here, statutory commands that "control" resolution of a decision; a vision that implicitly offers a range of choice, a sense of fit and aptness. That is, the task accepts that the "meaning" of the statute yields no discretion, unlike the choice of tools for its unlocking, an allowance of judicial "judgment" as the interpretative tool most apt. To the realist this may be seen as mere wordplay. I think it is more, that it reflects judicial reluctance to relinquish decisional control outright — a clinging to authority that could be weighed by tendentious animus but may well be little more than differing perceptions of judges of their judicial role. I suspect that many (most?) judges would see no unfaithfulness to legislative command in their choice of interpretative tools or variable intensity with which they are wielded.

FOLLOW-UP \#2. Whether a statute is sufficiently malleable to accommodate the accretive force of judicial decision rests in the tautological inquiry of its meaning — how much delegation to the courts is fairly locatable in text, history, etc., e.g. "unreasonable restraint of trade," mindful that the Congress acts against a backdrop of a judicial role that can serve to smooth out the bumps of the future within the ambits of its legislative objective. This dialogue between Congress and courts is often plain. See the meandering path of judicially supplied rights of private enforcement to congressional set norms, and the wielding of the plain statement rule, e.g. stepping on state sovereignty.

FOLLOW-UP \#3. When I come to [a] decision in review of the materials of the case runs the full range. To my eyes facts decide more cases than resolution of conflicting legal principles so in mine-run cases with settled legal principles, my effort is master the procedural history of the case and the detail of the facts ... what happened. As this varies with the case so follows the temporal point of decision. There remain cases where law and facts leave me yet uncertain post-argument and conference, not so rare with me. For those I take pen in hand and write 'til I have an answer.

\section{Post-Scalia Canonist/Moderate Textualist \# I}

QI. I wish I could say in all cases I have one approach but it is pretty random. I start a lot of cases with the district court decision. Sometimes I start with briefs. They often have a pretty good indication 
of what the statute says. If it is easy, it's easy. If it's hard then I will pull my statute out and keep broadening the lens until I figure out what's going on. I don't go to the statute first; I go to the briefs to get a sense.

Q2. In an area I don't understand, I don't think statutory interpretation cases are so different from other cases. I just keep reading until I get comfortable. If I have to start reading a secondary text, legislative history, other opinions concerning statutes, I will. I don't necessarily rely on everything I have read but I do keep reading. I don't go out and do extra research like sample experiments. I am very ecumenical.

I don't use "plain meaning." In interesting, challenging cases, we have the argument in front of us. I take the arguments as they are, so even if we go another way another court can see what we decided, why we didn't ignore the evidence, why we did what we did.

Q3. Dictionaries. Yes, I look at everything. I look at everything to make sure I am not wrong. I don't feel limited. On an issue of law, my gosh, I think the courts should figure it out.

$\mathrm{Q}_{4} \& \mathrm{Q}_{4} \mathrm{~A}$. Yes, we use the canons. This is probably an area where I am a fan of the Scalia/Garner book. I do agree, but we should be careful about every one of the canons. I find them useful but I don't buy the argument that for every one there is another one. They are useful. Be careful how you use them. You don't stop when you see a canon that resolves the case, you keep reading. I have always accepted the idea that courts can be consistent. It is useful to everyone. I am a huge fan of the rule of lenity. I wish it was used even more.

Q5. If I am anxious about an interpretation in front of me I will look at it [legislative history]. I definitely cite canons more than legislative history. It's right to be skeptical. Llewellyn would be more worried about legislative history: for every instance of legislative history you can find another one. I doubt I've ever used a statement on the floor. The one thing I use a lot I think is beyond reproach. I am very interested in the history of legislation. What they did in 'o9, ' 76 , how they changed the statute. It is very helpful in trying to understand the statutory background.

Q6. I am agnostic about [the value of judges understanding the legislative process]. I think it is helpful for a multimember court to have a lot of different backgrounds. It would be helpful to have a legislator on the court but I don't think we need more politics on the courts. But yes, it would be useful in FJC training. For someone like me I would go and I would learn things but it probably wouldn't affect me because I am very much where John Manning is on this. There are compromises. Learning the process won't help judges with that essential problem of not being able to get into the statutory deals. All you can do is look at the text agreed on. I agree with John Manning.

Q7. [On interpreting statutes to be consistent:] For terms of a statute enacted twenty years apart then yes that's an example of a canon that 
is imperfect but it is one worth following. It is a good thing to impose coherence. It is unfair to ask the reader to see terms of the statute differently. I get a little more nervous about one statute presuming consistency with other statutes. You have to be regional about it.

Q8. I extrapolate the purpose from legislative history but I have anxiety about cherry-picking. Legislative history gives judges a lot of options and expands the options but there is nothing wrong with that.

Q9. When it is obvious that Congress didn't contemplate the thing at all that's really hard. That is a good place to have canons and be consistent about it. Using canons consistently is a good thing. The instinct to do the interpretation that makes the most sense versus one that is canon driven is a hard tension. But I would probably pick the canons approach. I want to make the canons work with my policy instinct but I would probably side with the canon.

Q Io. Like most judges, when I get a case, I want to make it work. I want to make things coherent, and work better. I definitely start with that orientation, but I also am not afraid to say, "this is the language of a statute and is just too high of a hurdle." I am a big fan of judges taking that instinct and making sure the legislature knows about the problem. I'm not afraid to concur and let Congress or the Court know this is a problem. That can be very effective, especially in the Supreme Court, to concur.

QI I. I developed my approach by trial and error. I worked for two very different judges before. I read the literature both of you guys write. My fear of getting it wrong is a big driver for me.

QI2. I see myself associated with the methodological developments since the Ig8os. I start with the text; I don't jump to purpose so quickly. I don't see myself bound by Supreme Court methodology, but I do it because I kind of agree with them. But methodological change happens. It happened with King v. Burwell. That was a big moment. But it isn't math. It isn't a science, but I do think about the case in terms of hierarchy, like text first and as I go down the ladder I tend to think of things as less valuable and that's not bad. I don't even think the Court even thinks it is establishing methodological rules. The one thing I think would be valuable is I don't think we do a very good job in our conferences or opinions specifying where it is methodologically we are disagreeing.

QI3 \& QI4. I find the whole administrative law thing fascinating. It is shifting a bit. The Court is really reassessing Chevron itself. The last five, six, seven years I have paid a lot of attention to those cases. In my court when we get those cases and there is a lot of ambiguity I find myself not necessarily being as deferential as we were. I am sensing more skepticism among myself and my colleagues about deference and legal interpretation. I tend to be more deferential about factfinding. The whole idea behind Chevron is about the policy backbone, but what about implied delegation of judicial power? 
QI5. I don't even know what the labels mean. I know lots of textualists who don't do what I do and I know lots of purposivists that aren't doing that either. I think there is a hierarchy, things that are most helpful. I am a "quasi contextualist," maybe.

Qı6. Law clerks are the only friends I have! There are some limits as to what clerks can do. There is something wonderful about working with these smart people who are really excited and want to find answers. Several of my best opinions are ones that came out of back and forth with the clerks. I am very happy with what the law students are doing. We didn't have this course[, legislation,] when I was in school. As for the lawyers, yes and no, it depends. Lawyers from small practices you shouldn't expect them to do all this stuff. The older you get the more you can recognize the difference of the lawyers. I don't even feel obligated to read all the briefs from some of these practices.

QI7. I don't have any complaints [about how the federal courts are handling statutory cases or on the level of guidance currently from the Supreme Court].

\section{Post-Scalia Canonist/Moderate Textualist \#2}

QI. I don't even know I have a statutory interpretation case until I see the district court opinion. I always start with the district court opinion and then go to the briefs. I look at where the clause in question sits in the context - I look at where statutory provisions sit in the statute. I try to figure out what's the real text and where it sits.

Q2. [Redacted to preserve confidentiality.] [When there is ambiguity] one possibility is that this is a statute giving powers to an agency and in that case the agency can do whatever they want. If Congress has delegated to an agency, the rationale for letting the agency do something more, whether using policy or legislative history - stuff I try not to do - the rationale for the agency is that this is something that's been done by Congress, it's been dropped to the executive branch by Congress and if the executive branch isn't making a complete ass of itself, it has political legitimacy. If there is no agency and it's a pure litigation statute, the question is whether it's been delegated to us and if yes we should do something sensible. In my world, that's statutes like the Sherman Act. We proceed in common law fashion. I put that statute down and do not pretend there is an answer in the statute and find the answer in some other area of law. I don't torture the statute to produce an answer. If there's no answer, torture won't produce it. The question is then whether judges have authority to produce their own answer and they should then fess up that it's their own answer. Mead re-rationalizes Cherron as a case about delegation. If the contention is: this is ambiguous, then there is delegation. But in Chevron itself, much of what was going on in the Clean Air Act is that Congress had spotted a problem and told them to solve the problem of air pollution. That was a real 
delegation. A lot of times judges are talking about delegation, but nothing has really been delegated to the agency. Then I'm skeptical about using the Chevron approach. A lot of delegations are real and Chevron itself is a great example.

Q3. I'm not very confident about dictionaries. Dictionaries are words about how words have been used but don't tell you how words are used this time. What can be true about dictionaries is that uses of words change over time. If you are using a statute like the Rules of Decision Act, a midcentury statute, you ask how would Congress have understood the word "law" - would they have thought it means common law? We are such positivists we can't understand how "law" was used back then. I'd prefer to look at public debates to figure out what language means, but I'd rather look at Blackstone than to figure out myself what I think about the word now because I just don't know what they thought.

Q4. I mention [canons] largely to mock them. I've written opinions contrasting the canons like that the specific supersedes the general, etc. Karl Llewellyn was largely right about the canons, there are too many. One of the ones I particularly dislike is avoidance of constitutional questions - why shouldn't judges work hard to interpret constitutional questions?

[Redacted.] [There is a] principle of parsimony in language. Someone says "bring me an ashtray" - "one that isn't already nailed down" is implicit in that conversation. Everyone but a maniac understands that. You can conserve on language. The "cooperative principle" assume the speaker and the listener are cooperating, that is really a formula for some canons - like ejusdem generis, that's a form of the cooperative principle of speech, you assume the person can use the listed examples to make clear what they are talking about. I'm skeptical of the canons as if they were rules - many of them are just built into the way we talk. Now having said that, I'm less certain about how much cooperation we should assume. Many statutes aren't written on the assumption that people or judges are cooperating - like tax statutes aren't written thinking about how others are cooperating. When statutes are written to tie citizens' or judges' hands, then it's a mistake to believe that language is going to be construed cooperatively.

The rule of lenity? Do you call it a canon or constitutional principle? I view it as shorthand for [the] proposition that judges aren't supposed to create crime. The mail fraud statute is repeatedly the worst example in modern times. The McNally case cuts back on the mail fraud statute, Congress tries to reenact part of it, then Skilling cuts back on it again, that seems entirely proper. There is nothing there in the statute. That's entirely understandable. I don't know whether to call it a canon or an understanding of a constitutional norm about allocation of powers in government. 
Other things are also called canons, like clear statement rules. I don't think that's a canon for interpreting a statute that tells you about the meaning of the statute. Same with private rights of action, but it tells you what happens unless words say something. There may have been a compromise in Congress, we don't know what it was. Thank goodness the Supreme Court doesn't deal with Borak anymore and imply private rights of action to get more enforcement. Like everything else, law is expensive. There is a limited amount of it.

Q5. [On legislative history:] [Redacted.] The rules of civil procedure come with the notes. In these cases, those background docs are very useful. Also the meaning of some text depends on how interpreters speak so if there is some ambiguity, I don't think there is a rule against listening to how the committee used language — just as you'd look at how the New York Times uses language. The example is the case imposing tax on fruit [Nix $v$. Hedden]: does the interpreting committee think like a school child and/or like botanists? The judges looked at legislative history and the New York Times and concluded that both Congress and the general community thought like school children and not like botanists. Scalia has said that he too approves of using legislative history in this way.

Q6. Knowing something about the legislative process is helpful, but I don't agree with the whole-act rule. That canon strikes me as particularly wacky. Statutes get amended dozens of times by numerous different political coalitions. It's so long no one can figure out what's in it, the idea that something put in the act in 1976 should be read the same way if it uses the same language if that language is put in thirty years later is ludicrous. If [Professor Akhil] Amar wants people to read the same word in the Constitution the same way even if it was a word from I 787 compared to 1867 - it makes sense to read the original text in the same way because it all went through Wilson's committee on details he did everything he could to make that polyglot document consistent but beyond that I'm skeptical.

Q7. [Consistency:] It depends what kind of statute we are using. If you are looking at something like the Clean Air Act, enacted by so many different coalitions, making it consistent makes no sense, far better to look at what sense EPA has made of it and accept it unless it's wacky. If you are looking on the other hand at a single statute enacted in short language at one time, treating phrase $\mathrm{A}$ to undermine phrase B would really just make a mess of things. So you should try to make them work together - that's a more sensible project, using rules of grammar, etc.

Q8, Q9 \& Qıо. I do like the fact that Scalia and Gamer says we don't presume that Congress knows everything but we act as though they did because better to save than destroy. That's sensible. I think safe to presume Congress doesn't even read what it enacts that day. Nancy Pelosi on the Affordable Care Act said: "We have to enact it to see what's in it." 
QI I. [Not asked.]

QI2. [Relevance of the Supreme Court's methodology:] They increasingly cite dictionaries. I think legislative history use has gone down. Does their methodology bind us? To the same extent that it binds them. If they say our statutory methodology is we allow agencies to resolve ambiguity using things like legislative history and policy then that Chevron rule binds us because they say that's our interpretive rule. But on the question does one resort to legislative history, they have all said in majority opinions that unless the statute is ambiguous, legislative history shouldn't be used. I think that's binding. On the question of what makes a statute ambiguous, they haven't said what makes a statute ambiguous so there is nothing binding. They haven't announced a rule about that. Or on the questions that divide textualists like me and pragmatists like you - you have textualists and pragmatists on the Supreme Court and neither of them has been squelched by the other so why would judges on the courts of appeals feel squelched either way?

Just because they haven't [announced binding methodological rules] doesn't mean they can't. [Professor] Nick Rosenkranz wrote an article called Federal Rules of Statutory Interpretation. He says they could do this. I'm kind of glad we don't have Acts Interpretation Acts - other nations include every canon from Llewellyn's table. Sometimes states enact these things but they aren't always followed. [References to Gluck's and other literatures here omitted.]

QI3 \& QI4. [See answers to Q2.]

QI5. [One word:] I don't think there is any difference between textualist and contextualist, if there was it's eroded. I think that all good textualists are contextualists.

Qı6. We have a few reasonably sophisticated lawyers. My law clerks are much more helpful. At oral argument, lawyers are so defensive and scripted; it's very hard to have a real conversation with them.

QI7. [Not asked.]

Qr8. Constitutional law and statutory interpretation are on one side. We're supposed to be carrying out someone else's charge. The common law is very different. In the common law world, where there's a statutory delegation like the Sherman Act or a constitutional delegation like the Supreme Court's original jurisdiction, then we are the primary anchor. You have a different approach when you are carrying out other people's commands than when you are trying to figure out the best answer. The first thing you do is figure out whether the federal common law is legitimate. Look at ERISA, for example, figure out whether the job of making a federal common law of contracts is tasked to us and then own up to the idea we are making it up. That's a real common law power, it was tasked to us but we shouldn't look at a statute and say "I can't see they've passed power to me" but decide it anyway. If there isn't something you can look to to figure it out either the statutory case isn't justiciable or there is a common law power in courts and 
courts should say we are deciding this on [our] own and we aren't blaming you. Judges don't say that they are but they should.

\section{E. "Ex-Staffer": Younger-Generation Judge with Some Capitol Hill Experience}

QI. It depends [where to start]. There are some statutes where there is so much precedent that you don't even look at the statutory text, you just read the cases, like I 983 or AEDPA. But a statute with less ground I start with the text but always text in context, I never just read a phrase.

Q2. It is unclear what is meant by the phrase "plain meaning." But yes. Because I read it. I read plainly, so when I read it, what it seems to be plays a role.

Q3. No dictionaries, unless it's a medical case [then] I look in a medical dictionary. My law clerks look at it, everybody does that now. They all give me dictionary definitions. It drives me crazy.

Q4. I find the second category [policy canons] - I find those helpful. In a close case they actually inform my thinking. Linguistic canons, to be honest, I use after I have made up my mind to help draft the opinion. It's a good argument after the fact. If it fits the bill, even if it is not central to my thinking, if I think it will help someone else organize their thoughts I will throw it in.

Q4A. I couldn't do the job without access to legislative history. The canons that I find that are not helpful are the ones that presume a kind of artistry on Congress for drafting statutes.

Q5. Yes, definitely [I use legislative history]. I have not yet had a case where I went back and did an exhaustive search for legislative history. I am working now for instance on a [redacted] case. I have seen this statute before. I know Congress wanted a broad application [from] the legislative history so I used it and I find it helpful but I haven't had to do a law office full legislative history myself.

Q6. I do think this would be helpful [for judges to understand more about Congress]. I worked on [Capitol Hill] . . . I am no master of the intricacies about how Congress works but I do have a healthy understanding. You need to understand there is a slapdash quality to what happens. You should not expect a level of precision in statutes that isn't there. It is a healthy understanding to have to understand stuff that comes out of the process. No one has thought so much about comma placement, etc.

Q7. I don't worry much about [consistency]. Using the same word the same way across the statutes. I have only had one case where there was real scrivener's error. I was prepared to construe that statute the way Congress actually meant it.

Q8 \& Q9. Yes, [I will use purpose,] that's part of how to resolve ambiguity. Yes, I am going to read it the way Congress intended. When 
there is no ambiguity and you have to add something that Congress did not add, that's harder.

Qro. Yes. For a total absurd result, it is easy. You could trace the process and see how Congress got it wrong. That would be an easy case for not going with what was there. I would work really hard to find enough ambiguity to avoid an absurd result.

QI I. [On developing an interpretive approach:] I go case by case. I am so not a theorist. But we have informative experiences. I clerked for [redacted] [on the Court] and that term we had some bare-knuckle brawls with Justice Scalia about legislative history. You take away from that a pretty deep resistance to the kind of Scalia approach to text and appreciate looking at the statute more as a whole thinking about what Congress had in mind. More of a commonsense approach.

QI2. [On precedential weight of interpretive rules:] I can imagine a case where it sounds more like binding precedent on a particular statute, like for this statute look at legislative history, but not at the level of generality that they do it now. They are so incompetent I don't know what to do.

Qr3. [On whether the judge treats cases that come from district court differently from ones concerning agencies:] Because of Cheoron? Yes. Apart from Chevron not really, but yes. You have to layer on top of it this really strong deference.

QI4. I do think Chevron is sensible. We don't get many agency cases. At some level I like Chevron because it makes my job easier. Also, for me to think myself expert enough to go head to head with an agency would be a huge amount of work.

Q I5. Definitely not literalist or textualist. I like common sense.

QI6. Coming out of law school [law clerks] tend to know the Scalia and Garner approach pretty well. They may be more textualist than I am. They often give me five to eight pages of statutory text rather than really getting into the cases. I would love to get my law clerks past that. My law clerks care about statutes. I think lawyers are helpful. They are informative about the purpose of the statute.

QI7. As of right now I am more comfortable getting less guidance from the Supreme Court because I don't know what it would be. If Congress could pay more attention to remedies and retroactivity and stuff like that when they are drafting it would be a lot better. It would be better if Congress would think through the application of that statute, who gets to sue, what do they get to sue for, that would be helpful. In my court we don't have any real statutory interpretation theorists running around trying to rule things out so I am very comfortable where my court is. 


\section{F. D.C. Circuit Judge}

QI. I start with the standards of review and precedent so I know what my responsibilities are, and if it's an agency case whether I need to apply deference, that's where I start.

Q2. Again, it depends on context. I'm looking for plain meaning first - I look for common usage, context and purpose of statute - that alone tells me if it's plain meaning and that will end it alone. But if deference is due it's entirely different. I'm looking to see if the agency has built-in authority. And then if it's manifestly unreasonable or contrary to law. We have lots of agency cases so this is what we do all the time.

Q3. If I don't know the meaning or if [there is] more than one possible meaning I will sometimes go to dictionary use, but then I'd use more than one dictionary. I don't have a method of picking dictionaries and that's why I choose several - to make sure they all have a common meaning and agree. I only look at a dictionary if I'm scratching my head about the word. I don't go there a lot.

Q4 \& $\mathrm{Q}_{4} \mathrm{~A}$. I can't say I understand the differences between presumptions and canons, and all the different kinds. Some like the rule against superfluities, or that Congress is presumed to act within the bounds of the Constitution, or consistent usage, or presumptions against retroactive effect, and implied repeals, those things do come up and can be helpful guides in some cases and yes, we use them.

Q5. Occasionally I use legislative history. I think everyone is a little skeptical of legislative history and with good reason, but it has some purpose. I think committee reports are probably the best you can get - if there is something to be had out of it. A committee report that reflects the views of both houses, both parties. The sponsor/opponent statements are helpful to understand[ing] what the battle is all about it's not too illuminating but it helps me size up the issue. I certainly would not pin my judgment on legislative history, but it's illuminating and helps me understand the fight.

Q6. [In response to the question about making statutes drafted by multiple committees consistent:] For me that's a "whoa" moment, but if judges start worrying about that we are asking for trouble. It's the statute that's enacted and we have to live with it. It's a terrible mistake if we start fooling around with that info. Congress has got to understand how we are going to operate even if these assumptions are fictitious. I don't much care if a twenty-six-year-old who didn't go to law school wrote a section. Just like you don't want to figure out when law clerks do the drafting. The public doesn't say, well wait, that's an issue. I have no interest in knowing who is doing the drafting - just look at final product. . . . I do think it's important to understand Congress, because any knowledge is useful, but there are cases where that kind of info can be useful. ... 
Q7. Not a chance [that I try to interpret the legislative deal]. That's off base to me. I don't trust a lot of my colleagues, if I can do that they can do it too! I'm not going there. That's what they wrote. If it turns out they are very unhappy with what they wrote then revise it.

Q8 \& Q9. Yes, I cite purpose - purpose is very much part of the interpretive process, especially if it's there to be found and you aren't guessing. Purpose, structure, organization are really important. The [Affordable Care Act] subsidies case; the purpose of Congress was evident, it couldn't be missed. But that was different because it was a Chevron case too. Purpose matters a lot.

Qı \& Qı г. [Not asked.].

QI2. [On interpretive precedents from the Supreme Court:] I don't think their approaches are a useful guide. I don't much focus on approaches like textualism because I don't really know what it is, it's different in different cases. I very much follow precedents. There are certain frameworks in which appellate courts can and should operate and I'm comfortable with it. If they want to reverse it they can. I don't worry about who's on what side of a 5-4 vote and who interprets in what way.

QI3 \& QI4. [On Chevron:] I've gotten to the point where I don't much care, I can understand both sides of it. It does establish a framework that keeps us somewhat confined. The ultimate question is should the agency have a major role or not, and the Supreme Court has decided yes they should, and Congress hasn't overturned that judgment which they could have done. I'm just not sure that without the framework judges would do a better job than agencies. What I've come to believe is that as long as we are within a clear framework, it confines us in good ways. I think Chevron is relatively clear, I think Cheoron has some blurry edges and can be argued over sometimes and I love seeing scholars argue over step one and two, but in our circuit we have gotten into a routine in applying it. ...

Q I5. I won't pin myself to one word. The places I start all the time are what's my standard of review in this case, is the agency entitled to deference, and is there a precedent. That's how I start. If I've got text, I'm certainly looking to see if there is plain meaning, then purpose, context, and structure. But standard of review and precedent are always in the case.

Qi6. [On the role of lawyers/law clerks:] It depends on the lawyers and the clerks. The percentage of good lawyers on cases isn't as high as I'd like. They aren't my guiding light either way. [Law clerks] are looking more to learn from us. They know something about Chevron and canons, but haven't seen them in real context and really just want to learn.

QI7. [Not asked.]. 
QI8. I think judges have a limited role, but an important role, and I try my best to understand that role and act accordingly. I think constitutional questions and answers are more malleable based on the nature of the document and the history of inquiry. It's much looser. I don't feel that way about statutory interpretation. I feel there is a railroad track and I take the train. Common law we don't see it so much, so I don't even know what to say about it. It is common law in the loose sense in terms of developing meaning in statutes but not common law in the traditional sense.

FOLLOW-UP\# \#. If you meant an eclectic approach as distinguished from a categorical approach, then, yes, I agree that this is generally the approach followed by the appellate judges with whom I have worked. In my view, it is an approach that lies somewhere in between the theses espoused by Richard Fallon (The Meaning of Legal "Meaning"), and Eskridge and Frickey ("funnel of abstraction"). "Reasonable meaning" might be a good description, but not in the narrow way that Hart and Sacks defined reasoned decisionmaking. In any event, in my view, there is no controlling categorical approach that is routinely applied in every case. Context (meaning the question before the court) matters. And judicial deliberations matter.

FoLLOW-UP \#2. We construe the statute as written. It is not the role of judges to "update" statutes. There are many cases that present statutory questions that Congress did not foresee when drafting. Statutory purpose and language guide us.

FOLLOW-UP \#3. It is not possible to answer this question. My assessments of cases vary from case to case. 